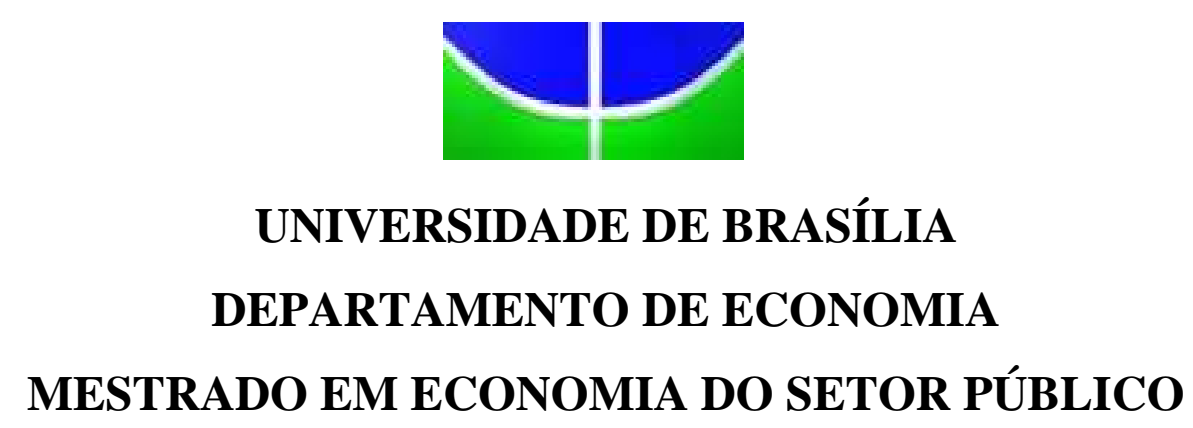

Thiago Paiva Chaves

RELAÇÃO ENTRE REMUNERAÇÃO DE ADMINISTRADORES E DESEMPENHO DAS COMPANHIAS BRASILEIRAS COM AÇÕES LISTADAS NA BM\&FBOVESPA 
Thiago Paiva Chaves

\section{RELAÇÃO ENTRE REMUNERAÇÃO DE ADMINISTRADORES E DESEMPENHO DAS COMPANHIAS BRASILEIRAS COM AÇÕES LISTADAS NA BM\&FBOVESPA}

Dissertação de Mestrado apresentada ao Departamento de Economia da Universidade de Brasília como requisito para obtenção do título de Mestre em Economia do Setor Público.

Orientador: Prof. Dr. Rafael Terra de Menezes

Brasília 


\section{AGRADECIMENTOS}

Ao meu orientador Rafael Terra pelos conhecimentos transmitidos que permitiram com que eu avançasse na pesquisa.

Aos meus pais, os responsáveis pela minha motivação nos estudos.

A minha esposa Juliana, pelo apoio, compreensão e paciência nas horas de ausência entre aulas, estudos e pesquisas. 


\section{Resumo}

Este trabalho tem o objetivo de verificar a existência de relação e o eventual impacto do desempenho operacional registrado pelas companhias abertas com ações listadas na BM\&FBOVESPA na remuneração dos seus administradores. Os dados utilizados para essa análise estão no formato de painel. Serão avaliadas também a existência de relação de diversas variáveis ligadas à estrutura de propriedade e à governança corporativa das companhias com a remuneração dos membros do conselho de administração e da diretoria. Embora seja um tema amplamente estudado na literatura internacional, há poucos estudos acadêmicos sobre o assunto no Brasil, principalmente envolvendo remuneração de administradores, tendo em vista que apenas a partir de 2009 foi possível ter acesso aos diversos elementos que compõem a remuneração desses executivos. A análise econométrica realizada para 331 companhias abertas, considerando o período de 2010 a 2014, revelou que para alguns elementos que compõe a remuneração dos executivos, como o pagamento em ações, há evidências de relação positiva e significativa entre remuneração e desempenho. Entretanto, para a maior parte das análises envolvendo essas variáveis, foram encontradas relações sem significância estatística ou significativas, mas pouco expressivas.

Palavras-chave: remuneração de administradores; desempenho das companhias; governança corporativa. 


\begin{abstract}
This study investigates the relationship and the impact of the company performance on executive compensation considering public companies listed on brazilian stock market, BM\&FBOVESPA. The data used for this analysis are in panel format. They are also analyzed in this study the relationship of different variables related to the ownership structure and corporate governance on executive compensation. Despite being widely studied topic in the international literature, there are few empirical studies on Brazil involving executive compensation, given that only from 2009 the components of the structure of executive compensation became public. The analysis of 331 public companies listed at BM\&FBOVESPA indicates a positive and significant relation between company performance and some components of the executive compensation, as stock plans. However, for most of the analyzes were found relationships with no statistical significance or significant but not expressive.
\end{abstract}

Keywords: executive compensation; company performance; corporate governance 


\section{Sumário}

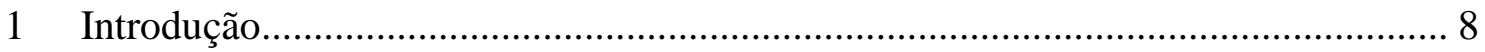

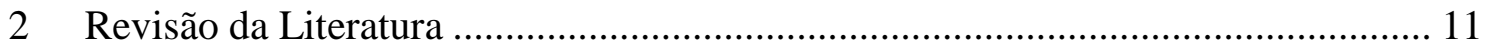

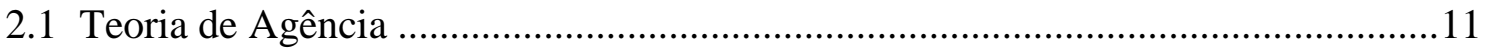

2.1.1 Relação Principal-Agente: modelo teórico ........................................................... 12

2.2 Regulação brasileira sobre remuneração do administrador....................................14

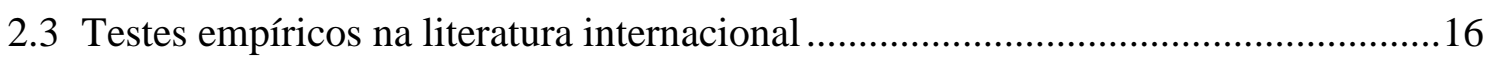

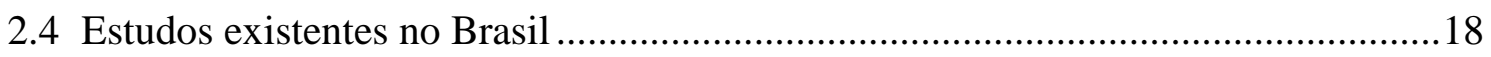

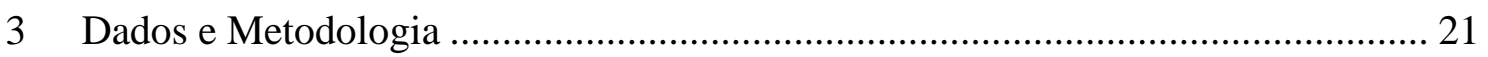

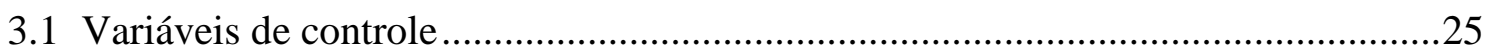

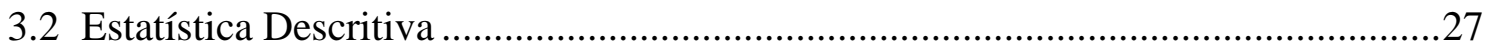

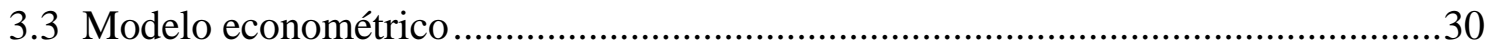

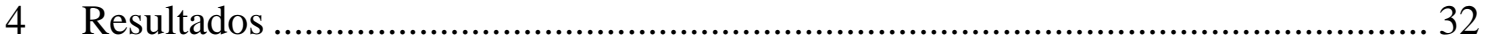

4.1 Remuneração fixa do conselho de administração ...................................................33

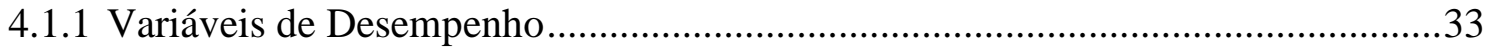

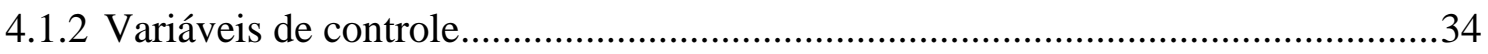

4.2 Remuneração variável do conselho de administração............................................35

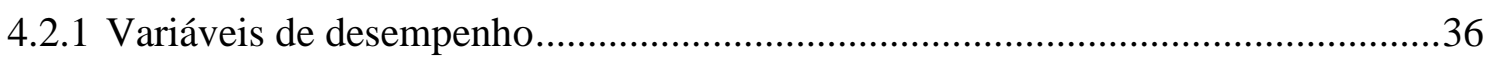

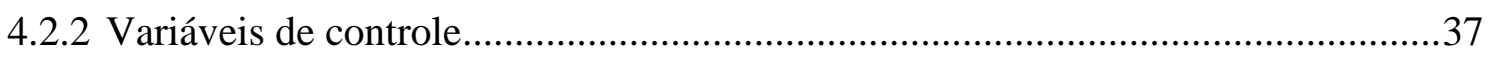

4.3 Remuneração em ações do conselho de administração ........................................... 37

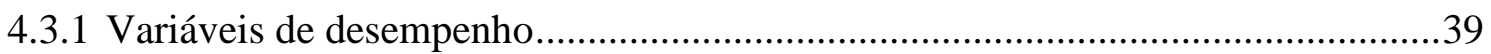

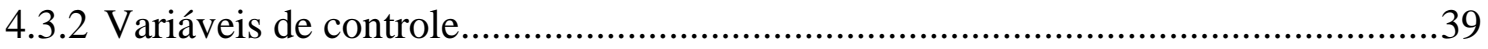

4.4 Remuneração total do conselho de administração...................................................39

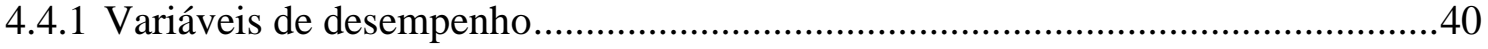

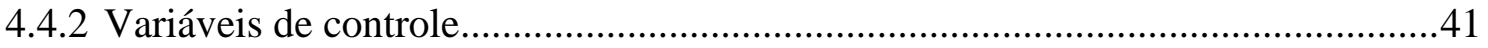




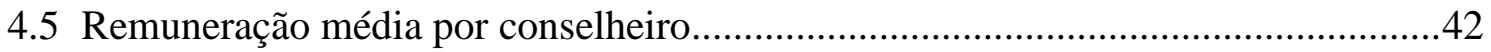

4.6 Maior e menor remuneração do conselho de administração .................................43

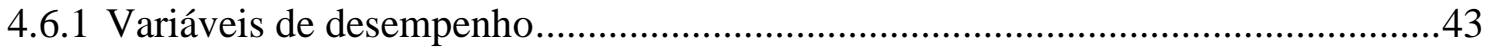

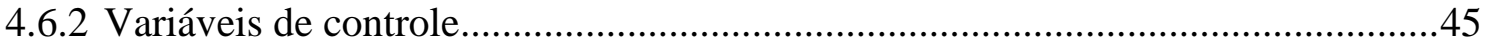

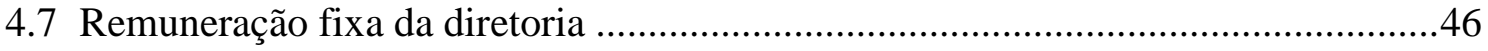

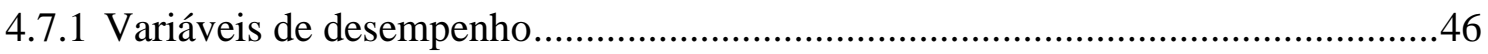

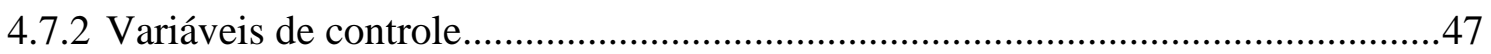

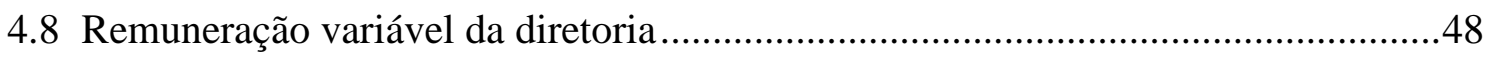

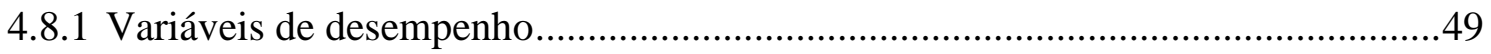

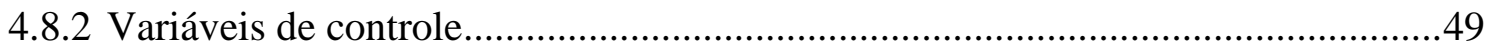

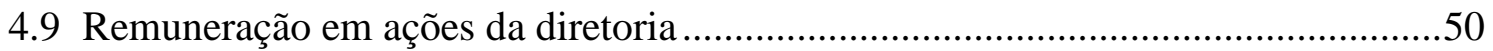

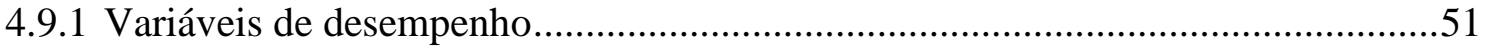

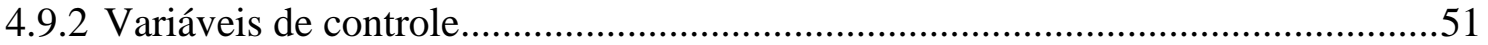

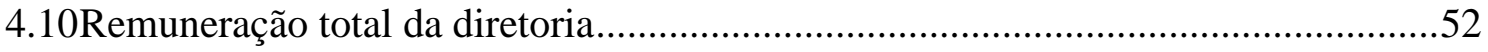

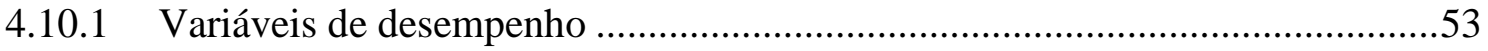

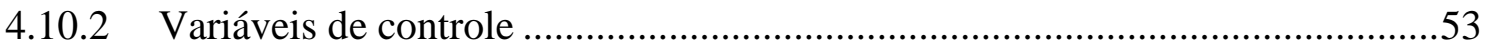

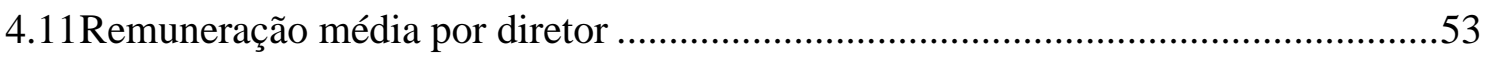

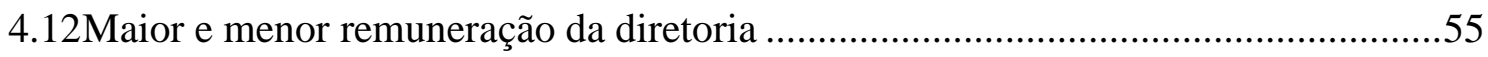

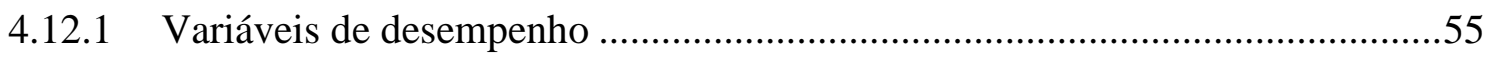

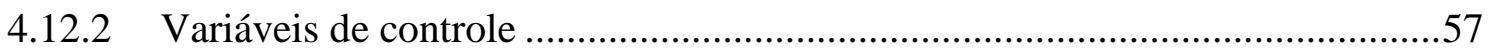

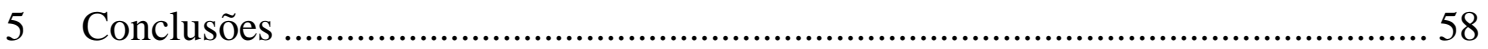

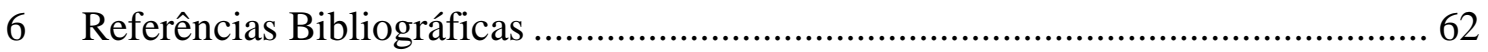

Quadro 1 - Matriz de correlação das variáveis não-binárias ......................................... 65 


\section{Introdução}

O presente trabalho tem o objetivo de verificar a existência de relação e o eventual impacto do desempenho operacional das companhias com ações listadas na BM\&FBOVESPA na remuneração dos seus administradores, utilizando-se para isso base de dados contemplando cinco exercícios financeiros, de 2010 a 2014. Variáveis ligadas à estrutura de propriedade e à governança corporativa das sociedades também serão utilizadas para verificar eventual relação com a remuneração dos executivos.

A relação entre o desempenho das companhias com ações listadas em bolsas de valores e a remuneração paga a seus administradores tem sido objeto de estudos nas últimas décadas pela literatura internacional (Bebchuk e Fried, 2003; Murphy, 1985; Duffhues e Kabir, 2007; Barontini e Bozzi, 2011; Jensen e Meckling, 1976; Shim, 2015).

Considerando que os acionistas das companhias têm o interesse em maximizar o seu investimento realizado, é natural que a remuneração estabelecida para os administradores passe a ser um dos incentivos importantes a ser pactuado, de forma a assegurar um nível de desempenho para a companhia em linha com as expectativas pretendidas pelos sócios das companhias.

Nos Estados Unidos, o tema envolvendo remuneração de administradores voltou a ganhar destaque no início dos anos 2000, após escândalos de corrupção envolvendo grandes companhias americanas, como a Enron, WorldCom, Tyco, Global Crossing, e, mais recentemente, na crise financeira evidenciada em 2008, em que foram identificados, além de manipulações nas demonstrações financeiras, abusos nas remunerações pagas aos executivos dessas companhias (Daniel, 2015).

Em decorrência desses fatos, houve significativo avanço na legislação societária americana em termos de governança e transparência ${ }^{1}$, facilitando com isso o estudo

\footnotetext{
${ }^{1}$ No ano de 2002, foi promulgada a lei Sabanes-Oxley Act (SOX). Entre os avanços estabelecidos por esta lei estão: (i) define as responsabilidades a cargo dos diretores da companhia e as penalidades administrativas e criminais; (ii) define serviços que são proibidos para os auditores independentes dentro das companhias que auditam; (iii) define as funções e nível de independência do comitê de auditoria em relação à direção da companhia; (iv) obriga a divulgação das principais transações envolvendo a diretoria e os principais acionistas da companhia e (v) obriga a divulgação das informações trimestrais e anuais sobre todo fato material não relacionado ao balanço patrimonial.
} 
acadêmico em virtude da maior quantidade de informações geradas e disponibilizadas pelas companhias.

No Brasil, há poucas análises comparando o impacto do desempenho operacional das companhias no pacote de remuneração recebido pelos diretores e conselheiros de administração dessas empresas, tendo em vista, provavelemtne, a dificuldade de se obter dados confiáveis sobre a remuneração desses executivos até o ano de 2009 (Chien, 2012; Araújo, 2016; Vasconcelos e Monte, 2013; Camargos e Helal, 2005).

A partir de 2009, o órgão regulador do mercado de capitais no Brasil, a Comissão de Valores Mobiliários (CVM), passou a exigir de todas as companhias abertas, por meio da Instrução CVM 480/2009, a divulgação de um conjunto de informações com o intuito de aumentar a transparência de atos por elas praticados. Com isso, a remuneração total paga para cada órgão da companhia passou a ser divulgada de forma padronizada e individualizada, assim como a remuneração mínima, máxima e média da diretoria estatutária e do conselho de administração.

Além de a instrução CVM 480/2009 ter disponibilizado informações mais confiáveis sobre a remuneração dos administradores, ela também passou a exigir que as companhias divulgassem sua estrutura acionária, identificando quem são os acionistas controladores e suas respectivas participações em ações. Essa informação também será utilizada no presente trabalho como variável de controle no modelo econométrico.

Antes de 2009, o levantamento dos controladores das companhias, assim como suas respectivas posições acionárias era extremamente difícil, pois não havia a divulgação padronizada exigida pela CVM, devendo aos interessados, levantar todos os atos divulgados pela Companhia de modo a verificar a existência de acordo de acionistas para o exercício do controle da Companhia.

Embora exista atualmente todas essas exigências do regulador brasileiro, algumas companhias possuem liminares na justiça para evitar a divulgação da remuneração dos administrados nos moldes atualmente solicitados ${ }^{2}$, além de outras companhias que simplesmente não divulgam a totalidade das informações conforme exigência da CVM. Esse fato, inclusive, pode gerar um viés de seleção nas estimativas, tendo em vista a possibilidade de apenas as companhias com melhor governança e mais transparentes serem analisadas.

\footnotetext{
${ }^{2}$ http://www.amecbrasil.org.br/ibgc-apoia-pedido-da-amec-de-transparencia-na-remuneracao-deadministradores/. Acesso em 21.6.2016.
} 
Mas não resta dúvida que houve um grande avanço se compararmos com as informações anteriores a 2009, quando as companhias divulgavam apenas um valor global referente à remuneração, muitas vezes não incluindo remunerações variáveis pagas ou outras informações relevantes referentes à composição dessa remuneração.

A análise deste trabalho se concentrou no levantamento de informação de 331 companhias abertas, que possuíam ações listadas na BM\&FBOVESPA durante o período analisado. Diversas companhias foram excluídas da base de dados por não haver informações suficientes disponíveis nos sistemas pesquisados, que foram basicamente o site da CVM e o banco de dados da Economática.

Atualmente, existem seis segmentos de listagem na BM\&FBOVESPA. De forma geral, os segmentos de listagem apresentam diferentes regras de governança corporativa, incluindo determinados direitos e garantias aos acionistas, assim como informações mais completas e abrangentes divulgadas aos investidores, além das obrigações já previstas em leis relacionadas ao mercado de ações brasileiro. Os segmentos utilizados neste trabalho são aqueles existentes desde $2010^{3}$, sendo eles: novo mercado, nível 2, nível 1 e básico.

Desse modo, o intuito do trabalho é verificar se a remuneração paga aos executivos de companhias abertas brasileiras é relacionada e afetada pelo desempenho dessas entidades. Também serão analisados o impacto de variáveis de controle, como tamanho da companhia, percentual de participação de ações e segmento de listagem na remuneração paga aos administradores.

\footnotetext{
${ }^{3}$ As diferenças entre esses segmentos de listagem estão nas regras de governança que as companhias decidem aderir, voluntariamente. Essas regras vão além daquelas obrigações que as companhias têm perante a legislação brasileira. O Novo Mercado, segmento de mais alta governança, estabelece como principais regras: (i) permite a existência somente de ações ON; (ii) no mínimo $25 \%$ de free float; (iii) esforços de dispersão acionária; (iv) composição mínima do conselho de administração é de cinco membros, sendo pelo menos $20 \%$ independentes e (v) concessão de tag along de 100\% para ações ON. Embora o segmento Bovespa Mais já existisse desde 2005/2006, não foi utilizada neste trabalho por ser direcionado às companhias de pequeno e médio portes e conter companhias que ainda não abriram capital. Site: http://www.bmfbovespa.com.br/; acessado em 11.8.2016 às $8 \mathrm{~h}$.
} 


\section{Revisão da Literatura}

\subsection{Teoria de Agência}

A remuneração dos administrados em sociedades anônimas tem sido objeto de diversos estudos acadêmicos nas últimas décadas, tendo em vista que neste tipo de sociedade é comum, sendo uma de suas facilidades, permitir que acionistas deleguem o poder decisório a executivos profissionais para exercer a administração da entidade (Pinto, 2011).

Ocorre que essa delegação muitas vezes revela interesses divergentes entre os agentes. Como os administradores são geralmente mais bem informados sobre as condições da companhia que os acionistas, surge um potencial conflito de interesse (Brunello, 1999).

Considerando também que os administradores tendem a ser maximizadores de sua própria utilidade, há razões para acreditar que eles não agirão no melhor interesse dos acionistas (Jensen e Meckling, 1976).

Na realidade, problemas envolvendo custo de agência e o seu monitoramento estão presentes não só em relação aos empregados contratados, mas permeiam todas as relações contratuais celebradas pela sociedade com fornecedores, clientes e credores (Jensen e Meckling, 1976).

De forma ampla, a teoria da agência lida com a forma pela qual os contratos e incentivos são estabelecidos entre o principal e agente (acionista e administrador, respectivamente, para efeitos deste trabalho) de modo que os agentes atinjam a maximização da riqueza do acionista, ou seja, os contratos desenhados devem motivar o agente a tomar decisões que melhorem a condição do acionista, reduzindo o conflito de interesse entre as partes (Anthony e Govindarajan, 2002).

Com isso, a teoria da agência busca resolver o problema existente nas organizações quando seus agentes possuem interesses divergentes, priorizando-os e deixando em segundo plano os assuntos da instituição e dos próprios acionistas.

Em relação à remuneração dos administradores, não há consenso na literatura internacional se ela poderia ser usada como uma ferramenta para a diminuição do custo de agência. Murphy (1999) defende a tese de que a remuneração poderia sim ser utilizada como um dos mecanismos para se reduzir o custo de agência, incluindo plano de opções baseado no 
desempenho da firma ou a outros indicadores de resultados, de forma a alinhar ao máximo os interesses entre acionista e administrador.

Outros estudos também indicam que os conflitos existentes entre administradores e acionistas podem ser reduzidos se a remuneração paga aos executivos for atrelada ao desempenho da empresa (Brunello, 1999; Rao e Lee-Sing, 1995; Krautep, 2009).

\subsubsection{Relação Principal-Agente: modelo teórico}

Há diversos estudos identificados na literatura em que são desenvolvidos e analisados modelos envolvendo a relação Principal (acionista) - Agente (administrador) e desenhos de contratos nos quais o Principal busca desenvolver incentivos de forma a induzir o Agente a tomar decisões de forma que maximize sua utilidade (Tirole, 1988; Stadler e Castrillo, 2001; Silva e Andrade, 2008).

Com base nesses modelos, o Principal busca maximizar o seu lucro, com o Agente participando com um nível de esforço $e$. A função lucro do Principal será:

$$
\pi=\theta-w(\theta)=\theta(e, \gamma)-w(\theta(e, \gamma)), \text { em que: }
$$

- $\quad \boldsymbol{\theta}$ : lucro da firma. Considerando a participação do Agente, temos que o lucro da firma passa a depender do nível de seu esforço, $\theta(e, \gamma)$, em que $\gamma$ é uma variável aleatória.

- $\quad \boldsymbol{w}(\boldsymbol{\theta})$ : o Principal oferece um salário ou bônus $w$ ao Agente, que é função do lucro realizado pela firma.

O Agente pode não aceitar o benefício estabelecido pelo Principal, caso entenda que o esforço despendido para receber $w$ resulte em uma utilidade menor do que aquela, caso optasse por não trabalhar (utilidade mínima), por exemplo. Esse nível mínimo de utilidade será chamado de utilidade reserva, $\mu^{0}$. O agente também incorre em custos para determinado nível de esforço, $c(e)$, a realizar.

Com isso, o problema do Principal é estabelecer um nível de esforço $e$ de modo que maximize seu lucro, considerando que precisa oferecer um contrato ao Agente que gere ao menos sua utilidade reserva. Temos assim: 
$\operatorname{Max}_{e} \pi=\theta(e, \gamma)-w(\theta(e, \gamma))$, sujeito a: $\quad w(\theta(e, \gamma))-c(e)=\mu^{0}$

Substituindo a restrição do Agente na função maximizadora do Principal temos:

$\operatorname{Max}_{e} \pi=\theta(e, \gamma)-c(e)-\mu^{0}$, e resolvendo pela condição de primeira ordem $\frac{\partial \pi}{\partial e}=0$, temos que o lucro do Principal será máximo quando: $\theta^{`}(e, \gamma)=c^{`}(e), \operatorname{com} e=e^{*}$.

O desafio do Principal é estabelecer instrumentos que incentivem o Agente a atingir o nível de esforço $e^{*}$, para que tenha sua função objetivo maximizada. Uma forma de criar esse incentivo seria estabelecer o salário ou bônus do Agente atrelado a um montante $\Delta$ do lucro do Principal e ao lucro da firma (que depende também de seu esforço). Então, temos: $w(\theta(e, \gamma))=\theta(e, \gamma)-\Delta$.

E o pagamento do agente seria: $w(\theta(e, \gamma))-c(e)=\theta(e, \gamma)-\Delta-c(e)$. Ao maximizar a função do Agente e fazer a primeira derivada (CPO), temos:

$\operatorname{Max}_{e} \pi=\theta(e, \gamma)-\Delta-c(e) ; \quad$ CPO: $\theta^{\prime}(e, \gamma)=c^{\prime}(e)$.

Dessa forma, o nível de esforço que o Agente escolherá será também $e^{*}$.

Esse seria um exemplo de desenho de contrato em que a remuneração, ou ao menos um dos elementos que compõem a remuneração paga aos administradores, poderia ser usada de forma a reduzir eventuais conflitos entre principal e agente, alinhando os interesses entre acionista e administrador, o que estaria de acordo com as teses defendidas em vários estudos da literatura internacional, entre eles, Murphy (1999), Brunello (1999), Rao e Lee-Sing (1995) e Krautep (2009).

Entretanto, Bebchuk e Fried (2003), entendem que a remuneração não pode ser pensada como uma ferramenta possível para a diminuição do custo de agência, vez que ela é parte, em si, do problema, com os administradores tendo grande participação em suas próprias remunerações. Nesse caso, a remuneração dos administradores refletiria uma espécie de extração de renda, "rent extraction", da riqueza dos acionistas e da própria companhia, não funcionando como um instrumento eficiente de redução de conflitos entre os agentes.

Bebchuk e Fried (2003) argumentam que o plano de remuneração dos executivos tende a ser formado por práticas existentes no mercado, aliado ao poder de influência detido pelos administradores das companhias em influenciar suas próprias remunerações; e os ditos contratos ótimos sozinhos não podem explicar adequadamente as práticas de remuneração oferecida aos administradores. 
Alguns estudos evidenciam que essa remuneração a mais destinada ao administrador por conta de sua influência na estruturação de suas próprias rendas pode ser relevante, tendo em vista que no ano de 2000, nos Estados Unidos, a remuneração dos CEO foi em média 7,89\% do lucro das 1.500 companhias analisadas (Balsam, 2002).

Considerando que os dispositivos legais envolvendo a elaboração e aprovação da remuneração dos administradores variam de um país para o outro, o próximo item se propõe a especificar como se dá este mecanismo com relação às sociedades anônimas com ações listadas na bolsa de valores brasileira.

\subsection{Regulação brasileira sobre remuneração do administrador}

No Brasil, compete aos acionistas, por meio da assembleia-geral, estabelecer o valor máximo da remuneração a ser paga ao conselho de administração e aos membros da diretoria (Lei $n^{\circ}$ 6.404/1976, art. 152), diferentemente, por exemplo, do que ocorre nos Estados Unidos, em que o conselho de administração possui amplos poderes para determinar a compensação dos executivos (Bebchuk e Fried, 2003).

Embora no Brasil seja atribuição dos acionistas estabelecer o montante global da remuneração dos administradores, regra geral, compete ao conselho de administração aprovar a remuneração dos diretores e sua própria remuneração, respeitando o montante fixado em assembleia. Algumas companhias listadas na BM\&FBOVESPA possuem comitês de recursos humanos ou de remuneração, órgãos criados para melhorar a governança e transparência no estabelecimento de políticas de remuneração para os administradores.

A partir de 2009, a CVM passou a exigir de todas as companhias abertas, por meio da Instrução 480/2009, um conjunto de informações com o intuito de aumentar a transparência de atos por elas praticados. Com isso, a remuneração total paga para cada órgão da companhia passou a ser divulgada de forma padronizada e individualizada, assim como a remuneração mínima, máxima e média, da diretoria estatutária e do conselho de administração. 
Além da exigência para que as companhias abertas divulguem as remunerações pagas aos administradores, a $\mathrm{CVM}^{4}$ divulga orientações sobre os procedimentos que devem ser observados no envio dessas informações. Entre as principais orientações estão:

(i) no que diz respeito aos indicadores de desempenho levados em consideração para a determinação de cada elemento da remuneração (...), o emissor deverá, sem a necessidade de explicitar metas internas estabelecidas, divulgar os indicadores por ele utilizados para aferir o desempenho individual ou da companhia, principalmente no que diz respeito às parcelas variáveis da remuneração, indicando se estes se baseiam, por exemplo, no resultado da venda de produtos e serviços, no resultado operacional da companhia, na receita líquida, EBITDA, valor de mercado das ações etc.

(ii) o emissor também deve apresentar todas as informações necessárias para compreensão da metodologia usada para estabelecer o valor e a forma de reajuste da remuneração (...), descrevendo as estruturas organizacionais envolvidas, a responsabilidade de cada um dos órgãos e membros envolvidos, bem como os critérios por eles utilizados.

O Instituto Brasileiro de Governança Corporativa (IBGC) ${ }^{5}$, organização sem fins lucrativos, produz diversas publicações e pesquisas com foco no desenvolvimento de boas práticas de governança para empresas. Periodicamente, o IBCG publica um documento chamado de Código das Melhores Práticas de Governança Corporativa.

Com relação à remuneração dos conselheiros de administração, o IBGC ressalta que a remuneração apropriada favorece o alinhamento de objetivos e evita conflitos de interesses entre acionistas, companhia e conselheiros. Entre as recomendações de boas práticas, indica que as organizações devem ter um procedimento formal e transparente de aprovação, pela assembleia geral, da remuneração dos conselheiros.

Sobre a remuneração da diretoria, a publicação do IBGC enaltece que a remuneração deve proporcionar o alinhamento de seus interesses com os da organização. Entre as recomendações de boas práticas, indica que (i) "a política de remuneração não deve estimular ações que induzam os diretores a adotar medidas de curto prazo sem sustentação ou que, ainda, prejudiquem a organização no longo prazo"; (ii) a remuneração da diretoria deve estar vinculada a resultados, com metas de curto e longo prazos relacionadas de forma clara

\footnotetext{
${ }^{4}$ OFÍCIO-CIRCULAR/CVM/SEP/No $02 / 2016$

${ }^{5}$ http://www.ibgc.org.br/index.php
} 
e objetiva a geração de valor econômico para a organização. (iii) ninguém deve estar envolvido em qualquer deliberação sobre sua própria remuneração. O diretor-presidente deve encaminhar para aprovação do conselho a proposta de remuneração da diretoria e (iv) o conselho deve submeter sua proposta dos valores e da política de remuneração da diretoria a aprovação da assembleia geral.

Considerando os dispositivos legais existentes no Brasil, incluindo as regulamentações e orientações editadas pela CVM, e as orientações publicadas pelo IBGC, há um indicativo de que a remuneração dos administradores poderia e deveria ser usada no Brasil de maneira a alinhar os interesses entre acionista, organização e administrador, reduzindo conflitos de interesses existentes, sendo assim uma possível ferramenta para a diminuição do custo de agência.

Entretanto, também com base na regulação existente no Brasil, é possível que administradores tenham uma grande participação na decisão de suas próprias remunerações, dependendo da estrutura de governança da companhia, podendo a remuneração ser parte em si do problema do custo de agência, conforme a tese defendida por Bebchuk e Fried, 2003.

\subsection{Testes empíricos na literatura internacional}

Há diversos testes empíricos na literatura internacional realizados para avaliar a relação entre o desempenho da companhia e a remuneração dos seus administradores. Os resultados encontrados são diversos, conforme abaixo mencionados, existindo estudos que evidenciam forte relação positiva e outros que encontram resultados estatisticamente não significativos ou até mesmo relação negativa entre as variáveis.

Nos Estados Unidos, o tema envolvendo remuneração de administradores voltou a ganhar destaque no início dos anos 2000, após escândalos de corrupção envolvendo grandes companhias americanas, como a Enron, WorldCom, Tyco, Global Crossing, e, mais recentemente, na crise financeira evidenciada em 2008, em que foram identificados, além de manipulações nas demonstrações financeiras, abusos na remuneração paga aos executivos dessas companhias (Daniel, 2015).

Com resultados positivos para esta relação entre remuneração de administradores e desempenho das companhias, estão os pesquisadores (Hubbard e Palia, 1975) que analisaram 
companhias do setor bancário americano e (Murphy, 1985) que, mesmo não encontrando forte correlação, concluiu que havia uma relação positiva entre essas variáveis.

Também em relação ao mercado de ações dos Estados Unidos, John et al. (1999) analisou 205 companhias entre 1982 e 1984. Seu trabalho buscou não só identificar eventual relação do desempenho das companhias com a remuneração recebida pelos administradores, mas também o impacto de variáveis explicativas ligadas à governança corporativa das companhias. Os resultados encontrados revelam forte relação do desempenho acionário das companhias na remuneração dos administradores. E em relação à estrutura de propriedade, os resultados demonstraram que quanto maior a concentração de ações menor é a remuneração dos administradores.

Ainda no mercado dos Estados Unidos, Shim (2015) analisou 232 companhias entre os anos de 1997 a 2010. O artigo teve como objetivo avaliar a participação do desempenho das companhias no pacote de remuneração pago aos executivos, considerando as novas leis americanas (Sarbanes-Oxley) que, como mencionado anteriormente, tiveram como objetivo aprimorar a legislação societária americana em termos de governança e transparência.

Nos dois períodos analisados por Shim, antes e após a edição das leis, foram encontrados resultados positivos e significativos nessa relação, sendo que antes das leis verifica-se que a variável explicativa "desempenho acionário" das companhias se relacionada de forma significativa com a remuneração dos administradores, e, após a edição da lei, essa relação é maior com o desempenho operacional contábil da companhia.

Também há estudos na Europa que indicam que o desempenho obtido pelas companhias impacta a remuneração recebida pelos seus administradores, sendo observada uma relação positiva entre essas variáveis. Entre esses estudos, trabalho de Elston e Goldberg (2003) no mercado acionário da Alemanha envolvendo também variáveis de governança corporativa, revelou forte correlação da remuneração dos administradores com o desempenho da companhia e com sua estrutura de controle.

Kaplan (1994) faz um comparativo entre o mercado japonês e o americano entre 1980 e 1988, encontrando uma relação positiva em ambos, mas uma sensibilidade maior do mercado americano na relação entre remuneração e desempenho das ações. Shakerin (2014) analisa 100 companhias listadas no mercado de ações da Malásia entre 2006 e 2010 encontrando relação significativa dessas variáveis, entretanto, nesse caso, foi utilizada a remuneração dos administradores como variável explicativa e, desempenho da companhia, como variável dependente. 
Também é possível encontrar diversos estudos na literatura internacional que concluem pela inexistência de relações positiva e significativa entre remuneração dos administradores e desempenho da companhia. Entre eles, Duffhues e Kabir (2007) analisam 135 companhias do mercado de ações Holandês. Durante 1998 e 2001 levantaram informações sobre o total de remuneração paga aos administradores juntos. Concluíram que o desempenho da companhia impacta a remuneração dos administradores, mas de forma negativa, considerando variáveis de desempenho operacional e de mercado.

Embora esses resultados apontem para a ideia de que a remuneração não seja um fator relevante para resolver o problema de Agência, Duffhues e Kabir (2007) afirmam também que esse resultado não deve ser interpretado como uma evidência de pagamentos exorbitantes para os executivos ("extração de renda"). Outras justificativas importantes, como atrair e manter talentos, devem ser considerados também.

Barontini e Bozzi (2011) analisam 215 companhias listadas no mercado de Milão, Itália, durante os anos de 1995 e 2002. Não encontram evidências de que o desempenho das companhias impacte o pacote de remuneração estabelecido aos administradores. Neste estudo, também utilizam diversas variáveis relacionadas à governança corporativa das companhias, como tamanho do conselho de administração e dispersão acionária e concluem que quanto maior a concentração de ações menor é a remuneração paga aos administradores.

Há diversos outros artigos pesquisados que apontam inexistência de relação significativa do desempenho das companhias com a remuneração dos seus administradores. Bart (2009) analisa 160 companhias listadas no mercado acionário Holandês entre 2002 e 2007, sem encontrar resultados significativos. No mercado Inglês, em pesquisa realizada com as 90 maiores companhias da Inglaterra entre 1992 e 1994, Mcknight (1996) também não encontrou relação significativa entre essas variáveis.

\subsection{Estudos existentes no Brasil}

No Brasil, ainda há poucos estudos empíricos sobre o assunto e boa parte dos trabalhos existentes não tratam da relação entre remuneração de administradores e desempenho da companhia, mas sim sobre a concentração de propriedade acionária existente 
nas companhias listadas no mercado acionário brasileiro (Canellas e Leal, 2009; Leal, Carvalhal da Silva e Valadares, 2002) e estudos sobre a relação entre dispersão de propriedade e remuneração (Pinto, 2011).

Uma das possíveis razões para a baixa quantidade de trabalhos nesta área consiste na dificuldade de obtenção de dados confiáveis sobre a remuneração dos administradores das sociedades anônimas no Brasil até 2009. A partir desta data, a CVM passou a exigir de todas as companhias abertas diversas informações para aprimorar a transparência e governança dessas sociedades, incluindo a divulgação detalhada das remunerações mínimas, máximas e médias pagas aos administradores, além dos critérios para eventual pagamento de remuneração variável.

Pinto (2013) analisa dados de 315 companhias abertas brasileiras no ano de 2009, data em que a CVM passou a exigir das companhias a divulgação de informações relacionadas à remuneração dos administradores e diversas outras, como relação de acionistas titulares de ações representando 5\% ou mais do capital total ou votante de cada companhia.

Embora o foco do seu trabalho tenha sido a relação entre remuneração de administradores e dispersão acionária, na regressão de um ano realizada foi encontrada relação estatisticamente significativa e negativa entre remuneração e desempenho. A variável de desempenho com um ano de defasagem também apresentou coeficientes negativos, mas não foi estatisticamente significativa.

Vasconcelos e Monte (2013) analisam 179 companhias abertas brasileiras no ano de 2009. Utilizam diversas variáveis mencionadas na literatura para medir desempenho da companhia, entre elas, Retorno sobre Ativos, Retorno sobre o Patrimônio Líquido e Dividendo por ação. Os resultados encontrados não permitem comprovar uma relação forte entre desempenho e remuneração. Na regressão utilizada, levando em consideração apenas a remuneração da diretoria, "a qual tem seus salários mais atrelados à remuneração variável, apenas o Retorno sobre o Patrimônio Líquido apresentou significância estatística. Nesse sentido, estes resultados parecem sugerir que as políticas de remuneração não estão sendo feitas considerando-se os resultados gerados pelas empresas".

O estudo elaborado por Araújo et al. (2015) considerou as 200 empresas com maior liquidez no ano de 2011 na BM\&FBOVESPA, sendo que a análise se baseou entre os anos de 2009 a 2011. A variável retorno ao acionista foi utilizada como medida para o desempenho das companhias da amostra. Foram testadas três técnicas da análise em painel: diferenciação, efeitos fixos e efeitos aleatórios. Apenas no modelo de efeitos aleatórios se notou 
significância estatística e positiva da variável retorno ao acionista com a remuneração dos administradores. As variáveis de 1 e 2 anos defasadas, de retorno ao acionista, também apresentaram significância estatística.

Chien (2012), ao analisar dados de 420 companhias listadas no Brasil no período de 2002 a 2009, ou seja, antes da ICVM 409, encontrou uma relação positiva e significativa entre remuneração executiva e valor da companhia, mas não encontrou evidências significativas que demonstrassem que companhias que melhor remuneram seus administradores apresentam melhor desempenho operacional.

Camargos e Helal (2005) encontraram uma relação positiva entre remuneração e desempenho, entretanto, analisaram apenas 29 companhias listadas na BM\&FBOVESPA. Eles optaram por analisar aquelas companhias com ADR (American Depositary Receipt), ou seja, companhias listadas no mercado brasileiro que emitem também papéis nos Estados Unidos, com lastro em ações brasileiras, regra geral. 


\section{Dados e Metodologia}

A análise deste estudo se concentrou no levantamento de informações de 331 companhias abertas, que possuíam ações listadas na BM\&FBOVESPA durante o período de 2010 a 2014. Diversas companhias foram excluídas da base de dados por não haver informações suficientes disponíveis nos sistemas pesquisados.

Atualmente, existem seis segmentos de listagem na BM\&FBOVESPA. Basicamente, os segmentos de listagem apresentam diferentes regras de governança corporativa, incluindo determinados direitos e garantias aos acionistas, assim como informações mais completas e abrangentes divulgadas aos investidores, além das obrigações já previstas em leis relacionadas ao mercado de ações brasileiro. Os segmentos utilizados neste trabalho são aqueles existentes desde $2010^{6}$, sendo eles: novo mercado, nível 2, nível 1 e básico.

Os dados utilizados para realizar as análises das regressões apresentadas neste trabalho foram retirados do software Economática e do site da CVM. Do sistema da Economática foram coletados os dados financeiros presentes nos balanços das companhias, e, do site da CVM, informações sobre remuneração de administradores e participação acionária, principalmente.

Cabe ressaltar a importância deste trabalho, tendo em vista que até 2009, antes da edição da Instrução normativa CVM 480/2009, faltavam dados públicos confiáveis sobre remuneração de administradores e participação acionária de companhias abertas com registros na CVM. A análise separada dos tipos de remuneração paga aos administradores, como remuneração fixa, variável, por ações, entre outras, ficava prejudicada por não haver exigência normativa para a divulgação pública e transparente dessas informações.

Após a edição dessa Instrução, exigiu-se que as companhias abertas divulgassem regularmente em um documento chamado de Formulário de Referência a remuneração separada de cada órgão, incluindo de forma detalhada todos os benefícios diretos e indiretos,

\footnotetext{
${ }^{6}$ As diferenças entre esses segmentos de listagem estão nas regras de governança que as companhias decidem aderir, voluntariamente. Essas regras vão além daquelas obrigações que as companhias têm perante a legislação brasileira. O Novo Mercado, segmento de mais alta governança, estabelece como principais regras: (i) permite a existência somente de ações ON; (ii) no mínimo $25 \%$ de free float; (iii) esforços de dispersão acionária; (iv) composição mínima do conselho de administração é de cinco membros, sendo pelo menos $20 \%$ independentes e (v) concessão de tag along de $100 \%$ para ações ON. Embora o segmento Bovespa Mais já existisse desde 2005/2006, não foi utilizada neste trabalho por ser direcionado às companhias de pequeno e médio portes e conter companhias que ainda não abriram capital. Site: http://www.bmfbovespa.com.br/; acessado em 11.8.2016.
} 
bônus, comissões, remuneração baseada em ações, opção de compra de ações, entre outros, recebidos pelos executivos.

Sobre a participação acionária, o avanço desta Instrução foi no sentido de exigir que as companhias abertas divulgassem no Formulário de Referência sua estrutura acionária, identificando os acionistas controladores, bem como os acionistas titulares de ações representando $5 \%$ ou mais do capital votante de cada companhia.

Neste trabalho, com base na grande maioria da literatura pesquisada sobre o assunto (Murphy, 1999; Barontini e Bozzi,2011; Duffhues e Kabir, 2007; Bart, 2009; Kaplan, 1994; Araújo et al., 2015; Shim, 2015; John et al.,1999; Pinto, 2013; Vasconcelos e Monte, 2013; Bart, 2009; Brunello, 1999; Carpenter, 2002; Elston e Goldberg 2003; Wan, 2013), utilizou-se nos modelos econométricos a remuneração dos administradores como variável dependente e o desempenho das companhias abertas como variável independente.

O racional desse modelo é que, para a formação do salário dos administradores, um dos elementos que deve ser utilizado é o desempenho da companhia. Busca-se estabelecer incentivos para os administradores, alinhados com os interesses da companhia e dos acionistas da companhia, que almejam em última análise aumentar suas riquezas. Para isso, necessário é que a companhia apresente melhor desempenho ao longo do tempo.

Em relação à variável desempenho, foram utilizados os desempenhos contemporâneos das companhias, além dos valores defasados em 1 e 2 anos, tendo em vista que a formação do salário dos administradores pode ser estruturada com o resultado obtido pela companhia não apenas no ano corrente, mas sim em um acumulado dos resultados de anos anteriores.

Há também trabalhos e artigos que apresentam regressões em que a remuneração dos administradores é a variável independente e o desempenho da companhia a variável dependente do modelo (Chien, 2012 e Shakerin, 2014). Nesse caso, busca-se avaliar, por exemplo, se administradores que recebem altas remunerações tendem a apresentar melhores resultados para a companhia.

Embora não se tenha encontrado na literatura artigos que analisem essas duas formas de estruturar os modelos econométricos, com um comparativo entre elas, verifica-se que ambas as formas são utilizadas para se analisar as relações entre desempenho de companhia e remuneração de administradores.

Isso indica ser possível haver um viés de endogeneidade dessas variáveis, tendo em vista que maior remuneração pode gerar maior desempenho, e que maior desempenho das 
companhias possa resultar em maiores remunerações para os administradores, havendo assim, simultaneidade entre uma variável e outra. Uma das soluções possíveis para corrigir eventuais problemas de endogeneidade é a utilização de variáveis instrumentais. Embora a pesquisa dessa ferramenta não tenha sido escopo deste trabalho, espera-se, entretanto, que o presente estudo possa servir de subsídio para futuras pesquisas avaliarem se eventuais variáveis financeiras ou econômicas disponíveis de serem coletadas em nosso mercado poderiam ser utilizadas para aquele fim.

Para avaliar a eventual relação do desempenho da companhia nos pacotes de remuneração pagos aos seus administradores procurou-se testar modelos por meio de regressões com dados em painel, utilizando variáveis de controle já testadas na literatura internacional e nacional, entre elas: tamanho da companhia, grau de dispersão de suas ações, tamanho dos órgãos do conselho de administração e diretoria (John et al.,1999; Duffhues e Kabir, 2007; Elston e Goldberg, 2003; Barontini e Bozzi, 2011; Palia, 1995; Chien, 2012; Pinto, 2013).

O modelo básico da regressão é apresentado a seguir:

- Remuneração $i_{i, t}=\beta_{0}+\beta_{1}$ Desemepnho $_{i, t}+\beta_{2}$ Desemepnho $_{i,(t-1)}+\beta_{3}$ Desemepnho $_{i,}(t-2)+$ $\beta_{4}$ Tamanho $_{i, t}++\delta_{1}$ Listagem $+\beta_{5}$ Propriedade $+\beta_{6}$ Lucro $+\beta_{7}$ Colegiado $(\text { tamanho })_{i, t}+$ $\beta_{8}$ Retorno $+\delta_{2}$ anos $+\varepsilon_{i, t}$

\section{$\underline{\text { Remuneração }}$}

É a variável dependente utilizada no modelo de regressão de dados em painel. Com base nos formulários de referência divulgados periodicamente pelas companhias no site da CVM foi possível trabalhar com diversas variáveis de remuneração para o conselho de administração e para a diretoria, sendo elas: remuneração fixa, variável, em ações, remuneração total, maior remuneração e menor remuneração.

A remuneração fixa contempla: salário ou pró-labore, benefícios diretos e indiretos, remuneração por participação em comitês e outros. A remuneração variável contempla: bônus, participação nos resultados, remuneração por participação em reuniões, comissões e outros. A remuneração total representa as remunerações fixa e variável, mais benefícios pósemprego, benefícios motivados pela cessação do exercício do cargo e remuneração baseada em ações, incluindo opções. 
A variável "maior remuneração" representa o valor da maior remuneração total paga individualmente a um conselheiro ou diretor, sem indicar nominalmente quem seria este administrador nem o cargo que exerce na companhia. Da mesma forma, a variável "menor remuneração" representa o valor da menor remuneração total individual.

Em relação à divulgação das maiores e menores remunerações do conselho de administração e da diretoria, há trinta e três ${ }^{7}$ companhias abertas que se utilizam de liminar obtida na justiça para não divulgar essas remunerações, exigidas em normativos pela CVM.

\section{Desempenho}

É a variável independente de interesse do modelo. Representa o retorno operacional sobre o ativo (ROA), ou seja, é um indicador que mede a eficiência operacional da companhia em gerar lucros a partir de seus ativos, sendo calculada pela divisão do lucro líquido da companhia pelo seu ativo total.

Nas regressões realizadas foi utilizada a variável ROA contemporânea ao pagamento das remunerações, além dos índices com 1 e 2 anos de defasagem.

A premissa adotada neste trabalho é que a remuneração dos administradores deve estar vinculada aos resultados financeiros e/ou econômicos divulgados pelas companhias que atuam. Em realidade, é esperado que os elementos variáveis da remuneração dos administradores, ou ao menos parte dessa remuneração variável, apresente uma relação significativa e positiva com o desempenho operacional da companhia (ROA), que é uma das principais variáveis utilizadas no mercado de capitais brasileiro para aferir o desempenho das companhias listadas na bolsa de valores.

Isso estaria em linha com parte da literatura internacional, que afirma que a remuneração poderia sim ser utilizada como um dos mecanismos para se reduzir o custo de agência, incluindo plano de ações, opções ou outra parcela variável baseado no desempenho da firma ou a outros indicadores de resultados, de forma a alinhar ao máximo os interesses entre acionista e administrador.

Já a parcela fixa da remuneração dos administradores tende a ser determinada considerando práticas adotadas conforme o setor de atuação, tamanho da companhia e segmento de listagem na bolsa de valores, variáveis que serão, inclusive, testadas e validades

\footnotetext{
${ }^{7}$ http://www.amecbrasil.org.br/ibgc-apoia-pedido-da-amec-de-transparencia-na-remuneracao-deadministradores/. Acesso em 21.6.2016.
} 
nas regressões realizadas neste trabalho. Parte da parcela fixa pode ser desenhada também para reter talentos, a depender do momento vivido pela companhia.

Conforme apresentado na Tabela 1, observa-se que a grande maioria das companhias abertas listadas na BM\&FBOVESPA remunera seu conselho de administração, principalmente, com uma parcela fixa; diferentemente da remuneração paga aos diretores, em que a parcela variável representa parte importante da composição total recebida por esses executivos, em torno de 55\%. Com isso, espera-se encontrar maior evidência de relação entre remuneração variável ou total com o desempenho operacional considerando os diretores das companhias.

A eventual existência de relação significativa e negativa entre a remuneração paga aos administradores e o desempenho das companhias poderia ser um indício, conforme argumenta Bebchuk e Fried (2003), que a remuneração não poderia ser pensada como uma ferramenta possível para a diminuição do custo de agência, vez que ela é parte, em si, do problema, com os administradores tendo grande participação em suas próprias remunerações, por exemplo; e que os ditos contratos ótimos sozinhos não podem explicar adequadamente as práticas de remuneração oferecida aos administradores.

Entretanto, para se confirmar tal afirmativa é preciso, incialmente, certificar-se de algumas situações. Uma delas é que a variável que representa o desempenho da companhia seja realmente a variável utilizada pelas companhias para o desenho da remuneração variável dos administradores. Neste trabalho, e conforme literatura sobre o assunto, adotou-se o ROA, como variável de desempenho utilizada pelas companhias, em função também, conforme mencionado, de ser um indicador amplamente utilizado no mercado brasileiro, não sendo o escopo deste trabalho testar ou esgotar as variáveis possíveis de serem utilizadas como medida de desempenho pelas companhias, de forma a confirmar qual delas seria realmente a mais indicada.

\subsection{Variáveis de controle}

\section{Tamanho}


Para representar o tamanho da empresa nos modelos econométricos deste estudo foi utilizado o logaritmo natural do ativo total da companhia. A literatura mencionada anteriormente sugere uma forte relação entre remuneração de administradores e tamanho da companhia, e vem se utilizando o ativo total como medida de tamanho.

\section{$\underline{\text { Listagem }}$}

Variável dummy para identificar aquelas companhas listadas nos segmentos de listagens da BM\&FBOVESPA com os maiores padrões de governança corporativas. Como critério para este trabalho, atribui-se um (1) às companhias listadas no Novo Mercado e Nível 2; e zero (0) para as companhias listadas no Nível 1 e no segmento tradicional.

\section{Propriedade}

A variável utilizada foi o percentual de capital votante do maior acionista da companhia. Essa variável é utilizada na literatura internacional para medir a estrutura de propriedade da sociedade, sendo um dos determinantes para a remuneração dos administradores.

\section{Colegiado (tamanho)}

Representa o número de membros no conselho de administração e diretoria.

\section{$\underline{\text { Lucro }}$}

O índice utilizado foi o lucro por ação da companhia (LPA), que representa a parcela do lucro líquido pertencente a cada ação emitida pela companhia. Seu cálculo é resultado da divisão do lucro líquido pelo número de ações emitidas pela sociedade.

\section{$\underline{\text { Retorno }}$}

Muitos trabalhos empíricos que analisam a questão da relação entre remuneração de administradores e desempenho das companhias utilizam o índice de retorno das ações, com 
base em suas cotações, como medida de desempenho. Entretanto, considerando que diversas companhias listadas na BM\&FBOVESPA apresentam baixa liquidez de negociação no mercado de ações, optou-se por não a utilizar como a principal variável independente de desempenho das regressões analisadas, em função de um número considerável de informações indisponíveis no sistema da Economática. Mas, manteve-se a variável em algumas regressões realizadas para avaliar a existência de eventual relação com a remuneração.

\section{$\underline{\text { Anos }}$}

Considerando que as variáveis dependentes dos modelos de regressão utilizadas neste trabalho contêm valores monetários e nominais, foram incluídas variáveis dummies para os períodos de tempo, exceto o período-base, de tal forma que não seja necessária a correção dos valores pela inflação, evitando a produção de resultados equivocados. As dummies temporais também têm como objetivo retirar eventual efeito macroeconômico que tenha afetado as companhias no período analisado.

\subsection{Estatística Descritiva}

A Tabela 1 contém as principais características das variáveis não-binárias mencionadas no item anterior e utilizadas nos modelos econométricos deste trabalho.

Tabela 1 - Características da amostra

\begin{tabular}{|c|ccccc|c|}
\hline & Média & Mediana & Desvio Padrão & Máximo & Mínimo & Amostra \\
\hline AF & 1.438 .190 & 736.772 & 2.863 .271 & 57.051 .236 & 554 & 1.361 \\
\hline AL & 1.573 .952 & 475.278 & 3.505 .900 & 30.744 .560 & 1.168 & 220 \\
\hline AR & 2.051 .024 & 808.472 & 6.231 .732 & 104.442 .465 & 554 & 1.383 \\
\hline AV2 & 290.161 & 116.660 & 873.791 & 15.291 .723 & 79 & 1.383 \\
\hline BR & 565.135 & 156.675 & 1.940 .293 & 50.113 .658 & 200 & 1.076 \\
\hline BS & 126.225 & 82.000 & 202.585 & 4.796 .000 & 200 & 1.045 \\
\hline AX & 5.269 .192 & 3.053 .470 & 12.245 .786 & 249.198 .764 & 1.676 & 1.408 \\
\hline BD & 5.671 .501 & 2.112 .785 & 14.315 .638 & 166.146 .671 & 2.424 & 1.006 \\
\hline BH & 5.922 .723 & 2.474 .500 & 10.854 .649 & 145.955 .470 & 3.000 & 468 \\
\hline BJ & 12.119 .588 & 5.228 .106 & 32.423 .061 & 454.346 .736 & 1.676 & 1.417 \\
\hline
\end{tabular}




\begin{tabular}{|c|ccccc|c|}
\hline BT1 & 1.691 .202 & 1.051 .460 & 2.060 .331 & 25.312 .053 & 559 & 1.417 \\
\hline BM & 2.119 .392 & 1.141 .277 & 3.149 .195 & 44.520 .615 & 1.676 & 1.104 \\
\hline BN & 718.130 & 481.292 & 899.489 & 12.718 .515 & 723 & 1.098 \\
\hline BX & 52 & 50 & 27 & 100 & 3 & 1.561 \\
\hline CL & 21.104 .803 & 2.247 .279 & 109.398 .189 & 1.437 .485 .512 & 1 & 1.601 \\
\hline CQ & -33 & 3 & 883 & 7.691 & -31.476 & 1.599 \\
\hline CR & -1.519 & 3 & 58.582 & 330 & -2.329 .860 & 1.582 \\
\hline CY1 & -3.831 & 3 & 89.395 & 330 & -2.373 .557 & 1.549 \\
\hline CO & -7 & 1 & 149 & 461 & -4.820 & 1.600 \\
\hline DA & 2,33 & $-2,98$ & 46,15 & 502,31 & $-94,52$ & 1.260 \\
\hline DTT & 25,41 & 7,75 & 71,97 & 569,54 & $-94,52$ & 1.213 \\
\hline AA & 7 & 7 & 3 & 23 & 0,03 & 1.448 \\
\hline AS & 6 & 5 & 7 & 91 & 1 & 1.443 \\
\hline
\end{tabular}

Período analisado: de 2010 a 2014. Variáveis relativas aos membros do conselho de administração - AF: remuneração fixa. AL: remuneração variável. AR: remuneração total (fixa + variável + outras). AV2: remuneração média dos membros do CA. BR: valor da maior remuneração entre os membros do CA. BS: valor da menor remuneração entre os membros do CA. Variáveis relativas aos membros da diretoria - AX: remuneração fixa. BD: remuneração variável. BH: remuneração em ações. BJ: remuneração total (fixa + variável + ações + outras). BT1: remuneração média. BM: valor da maior remuneração entre os membros da Diretoria. BN: valor da menor remuneração entre os membros da Diretoria. BX: percentual do capital votante do acionista com mais ações ordinárias, ON. CL: ativo total. M: variável binária - segmento de listagem (1 se listada no Novo Mercado e Nível 2, e 0 caso contrário). CQ: ROA: \% (Lucro líquido / Ativo Total) - ano corrente. CR: ROA_1: \% (Lucro líquido / Ativo Total) - 1 ano defasado. CY1: ROA_2: \% (Lucro líquido / Ativo Total) - 2 anos defasados. CO: LPA: (lucro líquido / total de ações). DA: percentual de retorno das ações em 12 meses - ano corrente. DTT: percentual de retorno das ações em 12 meses - 1 ano defasado. AA: número de membros no CA. AS: número de membros na diretoria.

Do universo de companhias analisadas entre 2010 e 2014, verifica-se que a média da remuneração fixa de todo o conselho de administração é de, aproximadamente, $\mathrm{R} \$ 1,44$ milhão por ano. Já a remuneração total, incluindo as partes fixa e variável, é de $\mathrm{R} \$ 2,05$ milhões, o que demonstra que, em média, mais de $70 \%$ da remuneração total do conselheiro de administração vem da parcela fixa. As medianas são bem mais baixas, R\$ 736.772 e R\$ 808.472, respectivamente, enquanto os desvios bastante elevados. Embora a média da parcela variável paga ao conselho seja alta, apenas há registros de pagamentos em apenas 220 observações $^{8}$. Já em relação à parcela fixa, foram 1.361 registros verificados.

Tendo em vista que a média de membros no conselho de administração, considerando as 331 companhias na amostra ao longo de 2010 a 2014, é de aproximadamente 7, a remuneração média por conselheiro é de $\mathrm{R} \$ 290.161$ ao ano. A mediana é de apenas $\mathrm{R}$ \$ 116.660 e o desvio padrão de $\mathrm{R} \$ 873.791$.

\footnotetext{
${ }^{8}$ Os campos em branco verificados podem ser em função da companhia realmente não remunerar seu conselho de administração ou pelo fato de a companhia não ter informado corretamente a informação no Formulário de Referência. Em função desse problema, os campos que estão com zero foram transformados para vazio.
} 
Quanto à diretoria, verifica-se que as remunerações são significativamente mais altas. A remuneração fixa de toda a diretoria é de, aproximadamente, R\$ 5,27 milhões por ano. Já a remuneração total, incluindo as partes fixa e variável, é de R\$12,11 milhões. No caso da diretoria, as remunerações variáveis e por ações representam parcela importante da composição total recebida por esses executivos. A parcela fixa representa aproximadamente $45 \%$ do total da remuneração total.

A remuneração média por diretor é de $\mathrm{R}$ \$ 1,69 milhão, mais de cinco vezes maior que a remuneração individual paga a um membro do conselho de administração. Assim como com as variáveis do conselho de administração, as medianas das remunerações da diretoria são bem menores que a média e os desvios padrão.

Em relação às variáveis de controle, nota-se que a estrutura de propriedade das companhias com ações listadas na BM\&FBOVESPA é bastante concentrada. O maior acionista detém, em média, $52 \%$ do capital votante da sociedade. Nesse caso, a mediana, $50 \%$, está muito próxima da média.

A variável utilizada para medir o tamanho da companhia (Ativo Total) apresenta elevada dispersão, sendo cerca de 5 vezes maior que a média encontrada, que é de R $\$ 21,1$ bilhões. A mediana é bem mais baixa, apenas $\mathrm{R} \$ 2,2$ bilhões, o que demonstra a grande diversidade das companhias listadas no mercado acionário brasileiro.

Ao analisar a matriz de correlação do Quadro 1, apresentada ao final deste trabalho, observa-se uma correlação positiva e significativa entre o tamanho da companhia e a maioria das variáveis utilizadas para a remuneração dos diretores e conselheiros de administração. Há outras variáveis, utilizadas nos modelos de dados em painel deste trabalho, como variáveis de controle, que apresentam correlação negativa com as remunerações dos administradores.

Já as variáveis que medem o desempenho das companhias, representadas pelos indicadores de desempenho contemporâneo e com defasagens de 1 e 2 anos, apresentam uma correlação muito próxima de zero, tanto comparando com a remuneração dos conselheiros quanto com a dos diretores. Entretanto, tendo em vista que a remuneração dos administradores está positivamente relacionada com o tamanho da firma e negativamente com outras variáveis de controle, devemos levar estes efeitos em consideração ao analisar a relação entre a remuneração dos administradores e desempenho da companhia. Para isso, far-se-á neste estudo várias regressões utilizando dados em painel. 


\subsection{Modelo econométrico}

Para avaliar a existência de relação entre remuneração de executivos e, principalmente, o desempenho das companhias abertas com ações negociadas na BM\&FBOVESPA foi utilizado neste trabalho estimação por dados em painel.

Um conjunto de dados em painel pode ser sintetizado como aquele que acompanha uma determinada amostra de unidades ao longo do tempo, fornecendo múltiplas observações sobre cada unidade na amostra (Hsiao, 2002). Em outras palavras, consiste em uma série temporal para cada registro do corte transversal do conjunto de dados (Wooldridge, 2010).

Embora seja mais difícil obter um conjunto de dados em painel, em função de requerer a repetição das mesmas unidades ao longo do tempo, há diversas vantagens nas regressões utilizando dados em painel comparadas com as outras formas de estruturas de dados, como a de cortes transversais agrupados.

Entre essas vantagens, de acordo com Hsiao (2002) e Wooldridge (2010) destacamse: permitir controlar certas características não observáveis das unidades utilizadas e analisar a importância das defasagens das unidades; aumentar o tamanho da amostra; investigar o efeito do tempo nos dados; acomodar a heterogeneidade e gerar menor colinearidade.

Neste trabalho, dois métodos foram realizados com dados em painel, efeitos fixos e efeitos aleatórios. No método de estimação por efeitos fixos (FE), todas as variáveis explicativas constantes no tempo são removidas, na tentativa de controlar possíveis vieses no poder explicativo das variáveis. De forma geral, este modelo tende a ser mais indicado quando supormos que esta variável, que capta todos os fatores não observados e constantes no tempo (efeito não observado), é correlacionada com as variáveis explicativas do modelo Wooldridge (2010).

Já se supormos que o efeito não observado é não-correlacionado com as variáveis explicativas é melhor usar o estimador de efeitos aleatórios. Em resumo, as hipóteses ideais de uso do método efeitos aleatórios incluem todas as hipóteses do método de efeitos fixos, com a adição desse requisito de independência entre o efeito não observado e todas as variáveis explicativas, em todos os períodos de tempo (Wooldridge, 2010).

Para avaliar a consistência destes estimadores, efeitos fixos e efeitos aleatórios, utiliza-se o teste de especificação de Hausman. O teste é uma ferramenta para avaliar ajustes desses modelos. Em caso de falha em rejeitar a hipótese nula ( $p$ valores não significativos) 
significa que os métodos de efeitos fixos e aleatórios são similares, mas as estimativas de FE são imprecisas, por causa de dados de baixa qualidade.

Embora a principal variável explicativa utilizada nas regressões deste trabalho, desempenho das companhias, não seja constante ao longo do tempo, há outras variáveis de controle de interesse que, por apresentam pouca variabilidade entre os anos analisados, podem resultar em variáveis não significativas nas regressões ao se utilizar o método de efeitos fixos. Nesse caso, como mencionado anteriormente, o efeito fixo não é uma opção desejável, tendo em vista que elimina as variáveis explicativas fixas ao longo dos anos.

Dessa forma, para todas as regressões realizadas, será feito o teste de hausman e testados os dois métodos, efeitos fixos e efeitos aleatórios. 


\section{Resultados}

Conforme mencionado anteriormente, para as diversas variáveis dependentes utilizadas nas regressões com dados em painel, foram rodados testes usando o método de efeitos fixos e efeitos aleatórios. O principal objetivo desse segundo método é avaliar o efeito das variáveis independentes que não variam de forma significativa para a mesma companhia ao longo dos anos analisados.

Inicialmente, buscou-se realizar regressões apenas com a principal variável independente de interesse dos modelos, qual seja, desempenho operacional das companhias (ROA), utilizando dados contemporâneos e dados com 1 (ROA_1) e 2 (ROA_2) anos de defasagem. Além dessas, adicionou-se a variável de controle que representa o tamanho da companhia.

Essas variáveis estão presentes em todas as regressões realizadas e estão apresentadas na coluna (1) da Tabela 2 a Tabela 15. Importante destacar que em função da maioria das regressões apresentadas na coluna (1) das tabelas mencionadas serem realizadas utilizando-se a remuneração total dos administradores, seja ela fixa, variável ou total geral, e não as respectivas remunerações médias, a análise deve ser feita com a devida parcimônia, por não haver variáveis de controle, por exemplo, para o tamanho do colegiado do conselho de administração e diretoria. Essas variáveis, entretanto, foram incluídas com diversas outras de controle na coluna (2) das mencionadas tabelas.

$\mathrm{Na}$ coluna (2) dessas tabelas, foram acrescentadas então variáveis de controle amplamente utilizadas nas literaturas internacional e nacional sobre o assunto (Barontini e Bozzi,2011; Duffhues e Kabir, 2007; Bart, 2009; Kaplan, 1994; Pinto, 2013; Vasconcelos e Monte, 2013; Chien, 2012). 


\subsection{Remuneração fixa do conselho de administração}

\subsubsection{Variáveis de Desempenho}

Na regressão utilizando o método de efeitos fixos, as variáveis de desempenho contemporânea (ROA) e defasadas em 2 anos (ROA_2) apresentaram sinais opostos em suas relações com a remuneração fixa do conselho de administração. Já a variável de desempenho defasada de 1 ano não apresentou coeficiente estatisticamente significativo, mesmo quando se incluiu as variáveis de controle, conforme tabela a seguir.

\section{Tabela 2 - Regressão: In natural de AF}

Variável dependente: logaritmo natural da remuneração fixa do conselho de administração

\begin{tabular}{|c|c|c|}
\hline \multirow[t]{2}{*}{ Regressão por Painel: } & \multicolumn{2}{|c|}{ efeitos fixos } \\
\hline & (1) & (2) \\
\hline $\begin{array}{l}\text { CQ } \\
\% \text { ROA }\end{array}$ & $\begin{array}{l}-0.001^{*} \\
(-1.874)\end{array}$ & $\begin{array}{l}-0.003 * * \\
(-2.267)\end{array}$ \\
\hline $\begin{array}{l}\text { CR } \\
\text { \% ROA defasado_1 ano }\end{array}$ & $\begin{array}{c}-0.000 \\
(-0.245)\end{array}$ & $\begin{array}{c}0.002 \\
(1.267)\end{array}$ \\
\hline $\begin{array}{l}\text { CY1 } \\
\text { \% ROA defasado_2 anos }\end{array}$ & $\begin{array}{c}0.000 * * * \\
(6.605)\end{array}$ & $\begin{array}{c}-0.000 \\
(-1.111)\end{array}$ \\
\hline $\begin{array}{l}\ln (\mathbf{C L}) \\
\ln (\text { ativo total) }\end{array}$ & $\begin{array}{c}0.222 * * \\
(2.448)\end{array}$ & $\begin{array}{c}0.279 * * * \\
(3.344)\end{array}$ \\
\hline M - dummy - segmento de listagem & & $\begin{array}{c}0.273 \\
(1.278)\end{array}$ \\
\hline $\mathbf{B X}$ - \% votante do maior acionista & & $\begin{array}{c}-0.002 \\
(-1.190)\end{array}$ \\
\hline $\begin{array}{l}\text { AA } \\
n^{\circ} \text { membros do CA }\end{array}$ & & $\begin{array}{c}0.104 * * * \\
(3.872)\end{array}$ \\
\hline $\begin{array}{l}\text { AS } \\
n^{\circ} \text { membros da Dir. }\end{array}$ & & $\begin{array}{c}0.010 \\
(0.456)\end{array}$ \\
\hline $\begin{array}{l}\text { CO } \\
\text { LPA (lucro por ação) }\end{array}$ & & $\begin{array}{l}-0.000 \\
(-0.023)\end{array}$ \\
\hline $\begin{array}{l}\text { DA } \\
\text { retorno ação }\end{array}$ & & $\begin{array}{c}0.000 \\
(0.225)\end{array}$ \\
\hline $\begin{array}{l}\text { DTT } \\
\text { retorno ação_1 ano }\end{array}$ & & $\begin{array}{c}0.001 \\
(1.144)\end{array}$ \\
\hline $\mathbf{R}^{2}$ within & 0.20 & 0.24 \\
\hline $\mathbf{R}^{2}$ overall & 0.20 & 0.23 \\
\hline Obs. & 1322 & 1020 \\
\hline Teste de hausman (p-valor) & erro & 0.8156 \\
\hline
\end{tabular}

\begin{tabular}{|c|c|}
\hline (1) & (2) \\
\hline $\begin{array}{c}-0.001 * * \\
(-2.398)\end{array}$ & $\begin{array}{c}-0.002 * * \\
(-2.015)\end{array}$ \\
\hline $\begin{array}{c}-0.000 \\
(-1.562)\end{array}$ & $\begin{array}{c}0.002 \\
(1.549)\end{array}$ \\
\hline $\begin{array}{c}0.000 * * * \\
(12.026)\end{array}$ & $\begin{array}{c}-0.000 \\
(-0.942)\end{array}$ \\
\hline \multirow[t]{8}{*}{$\begin{array}{c}0.278 * * * \\
(7.230)\end{array}$} & $\begin{array}{c}0.204 * * * \\
(5.269)\end{array}$ \\
\hline & $\begin{array}{c}0.171 \\
(1.412)\end{array}$ \\
\hline & $\begin{array}{c}-0.004 * * \\
(-2.318)\end{array}$ \\
\hline & $\begin{array}{c}0.094 * * * \\
(4.394)\end{array}$ \\
\hline & $\begin{array}{l}0.017 * \\
(1.761)\end{array}$ \\
\hline & $\begin{array}{c}-0.000 \\
(-0.210)\end{array}$ \\
\hline & $\begin{array}{c}0.000 \\
(0.317)\end{array}$ \\
\hline & $\begin{array}{c}0.001 \\
(1.190)\end{array}$ \\
\hline 0.20 & 0.23 \\
\hline 0.20 & 0.24 \\
\hline 1322 & 1020 \\
\hline
\end{tabular}

A variável dependente é representada pela remuneração fixa (salário, benefícios diretos e indiretos, participação em comitês e outros pagamentos fixos) paga a todos os membros do conselho de administração. As variáveis CQ, CR e CY1 medem o desempenho operacional, com as duas últimas sendo variáveis com 1 e 2 anos de defasagem, respectivamente. Tamanho da 
firma está representa pela variável ln $(\mathrm{CL})$. A variável dummy M indica se determinada companhia está (1) ou não está (0) nos segmentes de listagem Novo Mercado e Nível 2. A variável BX representa o percentual do capital votante do acionista com mais ações ON no período. As variáveis AA e AS representam, respectivamente, o número de membros do Conselho de Administração e da Diretoria das sociedades. A variável CO representa o lucro por ação. As variáveis DA e DTT representam o retorno da ação mais negociada da companhia, sendo a DTT com 1 ano de defasagem. A regressão contém variáveis dummies de ano (2011 a 2014). A estatística t está indicada em parênteses. ***, **, * indicam as significâncias aos níveis de $1 \%, 5 \%$ e $10 \%$, respectivamente.

Pela coluna (1) da Tabela 2, observa-se que um aumento (redução) de 10\% na variável ROA leva a uma redução (aumento) da remuneração fixa do conselho em 1\%. Já o desempenho defasado em 2 anos, apresenta correlação positiva com remuneração, entretanto, o impacto é bem reduzido, abaixo de $0,5 \%$, irrelevante em termos concretos. A $5 \%$ de significância, a variável de desempenho contemporânea não seria relevante estatisticamente.

Quando acrescentamos todas as variáveis de controle na regressão utilizando efeitos fixos, coluna (2), ROA_2 não é estatisticamente significante, mas o desempenho contemporâneo permanece significativo, com um aumento (redução) de 10\% no ROA levando a uma redução (aumento) de 3\% na remuneração fixa do conselho.

Já na regressão utilizando o método de efeitos aleatórios, embora com algumas diferenças em termos de significância estatística, não há grandes mudanças nos valores dos coeficientes que apresentam a correlação entre as variáveis de desempenho e remuneração.

\subsubsection{Variáveis de controle}

Conforme já explicado, como há variáveis de controle que não variam de forma significativa para a mesma companhia ao longo dos anos testados, foram rodadas regressões por painel utilizando efeitos aleatórios para analisar estas variáveis.

A variável que representa o tamanho da empresa neste modelo, logaritmo natural do ativo total $-\ln (\mathrm{CL})$, foi estatisticamente significativa em todas as regressões realizadas, tanto pelo método de efeitos fixos quanto por efeitos aleatórios. Em média, aumento de 10\% na variável tamanho da companhia levou a um aumento de $2 \%$ na remuneração fixa do conselho. Ou seja, quanto maior a companhia, “ceteris paribus", maior será a remuneração fixa do conselho de administração. Esse resultado está de acordo com a literatura internacional e nacional pesquisada e mencionada no início desse capítulo.

A variável de controle utilizada como correspondente à estrutura de propriedade da companhia (BX) representa o percentual votante do maior acionista da companhia. O 
coeficiente verificado na coluna (2) pelo método efeitos aleatórios é estatisticamente significativo. Em média, um aumento de $10 \%$ na participação votante do maior acionista reduz a remuneração do conselho de administração em $4 \%$.

Esses resultados demonstram que companhias com controle minoritário/disperso pagam mais a seus conselheiros, "ceteris paribus ", do que companhias que possuem um acionista como controlador ou com grande participação de ações votantes. Esse resultado está de acordo com a literatura internacional e nacional pesquisada e mencionada no início desse capítulo.

Cabe destacar também a forte correlação positiva existente entre remuneração fixa do conselho e quantidade de membros que compõem este próprio colegiado. Também há correlação positiva e significância estatística a $10 \%$ entre remuneração fixa e $\mathrm{n}^{\circ}$ de membros da diretoria da companhia. Para cada membro adicional participando no colegiado do conselho, a remuneração fixa do conselho aumenta em 9,4\%. Já para um diretor adicional, a remuneração fixa do conselho aumenta $1,7 \%$. Ressalta-se que a análise sobre se o aumento de um conselheiro de administração aumenta a remuneração média do conselho como um todo será feita apenas para a remuneração total do conselho (item 4.5), considerando as parcelas fixa, variável, entre outras existentes.

As variáveis que representam o retorno da ação da companhia nos últimos 12 meses, contemporânea e defasada em 1 ano, não apresentaram resultados significativos, assim como a variável CO.

\subsection{Remuneração variável do conselho de administração}

Importante destacar que em função da remuneração paga aos membros do conselho de administração ser em grande parte composta por parcela fixa, há poucos registros e, consequentemente, poucas observações a serem utilizadas nas regressões para a parcela variável da remuneração do conselho. De acordo com a Tabela 3 é possível observar que há menos de 220 registros de companhias que pagaram seus conselheiros utilizando-se de remuneração variável, durante o período de 2010 a 2014. Para as regressões com a remuneração fixa analisadas no item anterior, por exemplo, foram encontradas entre 1020 e 1322 observações para o mesmo período. 


\section{Tabela 3 - Regressão: In natural de AN1_var}

Variável dependente: logaritmo natural da remuneração variável do conselho de administração

\begin{tabular}{|c|c|c|c|c|}
\hline \multirow{2}{*}{$\begin{array}{ll} & \text { Regressão por Painel: } \\
\text { Variáveis } & \end{array}$} & \multicolumn{2}{|c|}{ efeitos fixos } & \multicolumn{2}{|c|}{ efeitos aleatórios } \\
\hline & (1) & (2) & (1) & (2) \\
\hline $\begin{array}{l}\mathbf{C Q} \\
\% \mathrm{ROA}\end{array}$ & $\begin{array}{l}-0.031 * \\
(-1.855)\end{array}$ & $\begin{array}{c}0.007 \\
(0.709)\end{array}$ & $\begin{array}{c}-0.014 \\
(-1.000)\end{array}$ & $\begin{array}{c}0.007 \\
(0.820)\end{array}$ \\
\hline $\begin{array}{l}\text { CR } \\
\% \text { ROA defasado_1 ano }\end{array}$ & $\begin{array}{c}-0.005 \\
(-0.149) \\
\end{array}$ & $\begin{array}{c}-0.034 \\
(-1.201) \\
\end{array}$ & $\begin{array}{c}0.008 \\
(0.276) \\
\end{array}$ & $\begin{array}{c}-0.018 \\
(-0.803) \\
\end{array}$ \\
\hline $\begin{array}{l}\text { CY1 } \\
\text { \% ROA defasado_2 anos }\end{array}$ & $\begin{array}{c}0.000 \\
(0.016)\end{array}$ & $\begin{array}{c}-0.026 \\
(-1.314)\end{array}$ & $\begin{array}{l}0.000 * * \\
(2.197)\end{array}$ & $\begin{array}{c}-0.014 \\
(-0.999)\end{array}$ \\
\hline $\begin{array}{l}\ln (\mathbf{C L}) \\
\ln (\text { ativo total) }\end{array}$ & $\begin{array}{c}0.091 \\
(0.340)\end{array}$ & $\begin{array}{c}0.025 \\
(0.118)\end{array}$ & $\begin{array}{l}0.235 * * \\
(2.431)\end{array}$ & $\begin{array}{c}0.120 \\
(1.055)\end{array}$ \\
\hline M - dummy - segmento de listagem & & $\begin{array}{c}0.000 \\
(.)\end{array}$ & & $\begin{array}{c}0.694 \\
(1.316)\end{array}$ \\
\hline BX - \% votante do maior acionista & & $\begin{array}{l}0.029 * * * \\
(5.065)\end{array}$ & & $\begin{array}{c}0.018 * * \\
(2.571)\end{array}$ \\
\hline $\begin{array}{l}\text { AA } \\
n^{\circ} \text { membros do CA }\end{array}$ & & $\begin{array}{c}0.118 * * * \\
(3.358)\end{array}$ & & $\begin{array}{c}0.057 \\
(1.324) \\
\end{array}$ \\
\hline $\begin{array}{l}\text { AS } \\
n^{\circ} \text { membros da Dir. }\end{array}$ & & $\begin{array}{c}0.077 \\
(0.806) \\
\end{array}$ & & $\begin{array}{c}0.025 \\
(1.137) \\
\end{array}$ \\
\hline $\begin{array}{l}\text { CO } \\
\text { LPA (lucro por ação) }\end{array}$ & & $\begin{array}{c}-0.012 \\
(-1.073)\end{array}$ & & $\begin{array}{c}-0.014 \\
(-1.034) \\
\end{array}$ \\
\hline $\begin{array}{l}\text { DA } \\
\text { retorno ação }\end{array}$ & & $\begin{array}{c}-0.001 \\
(-0.785)\end{array}$ & & $\begin{array}{c}-0.001 \\
(-0.786)\end{array}$ \\
\hline $\begin{array}{l}\text { DTT } \\
\text { retorno ação_1 ano }\end{array}$ & & $\begin{array}{c}0.001 \\
(0.703) \\
\end{array}$ & & $\begin{array}{c}0.001 \\
(0.691) \\
\end{array}$ \\
\hline $\mathbf{R}^{2}$ within & 0.05 & 0.27 & 0.04 & 0.26 \\
\hline $\mathbf{R}^{2}$ overall & 0.00 & 0.00 & 0.07 & 0.01 \\
\hline Obs. & 217 & 190 & 217 & 190 \\
\hline Teste de hausman (p-valor) & 0.1565 & 0.0211 & & \\
\hline $\begin{array}{l}\text { A variável dependente é representada pela rem } \\
\text { e outras remunerações variáveis) paga a todo } \\
\text { medem o desempenho operacional, com as d } \\
\text { Tamanho da firma está representa pela variáve } \\
\text { não está (0) nos segmentes de listagem Novo } ~ \\
\text { acionista com mais ações ON no período. As } \\
\text { Conselho de Administração e da Diretoria da } \\
\text { DTT representam o retorno da ação mais ne } \\
\text { contém variáveis dummies de ano ( } 2011 \text { a } \\
\text { significâncias aos níveis de } 1 \%, 5 \% \text { e } 10 \% \text {, res }\end{array}$ & $\begin{array}{l}\text { nus, partici } \\
\text { nselho de } \\
\text { riáveis com } \\
\text { dummy M } \\
\text { variável BX } \\
\text { epresentam } \\
\text { vel CO rep } \\
\text { a, sendo a }\end{array}$ & $\begin{array}{l}\text { ção em reun } \\
\text { ministração. } \\
\text { e } 2 \text { anos d } \\
\text { dica se dete } \\
\text { epresenta o } \\
\text { espectivame } \\
\text { senta o lucr } \\
\text { TT com } 1 \text { a }\end{array}$ & $\begin{array}{l}\text { participaçã } \\
\text { variáveis C } \\
\text { efasagem, re } \\
\text { lada compan } \\
\text { entual do cal } \\
\text { o número } \\
\text { r ação. As } \\
\text { de defasager } \\
\text { es. ***, **, }\end{array}$ & $\begin{array}{l}\text { le resultado } \\
\text { CR e CY } \\
\text { ectivamente } \\
\text { a está (1) or } \\
\text { l votante d } \\
\text { membros d } \\
\text { iáveis DA } \\
\text { A regressã } \\
\text { indicam a }\end{array}$ \\
\hline
\end{tabular}

\subsubsection{Variáveis de desempenho}

Considerando um nível de significância de 5\%, as variáveis de desempenho não são estatisticamente significantes, conforme Tabela 3. Com isso, não há evidências que o desempenho operacional das companhias tenha participação na remuneração variável do conselho de administração. 


\subsubsection{Variáveis de controle}

Ao adicionar variáveis de controle nas regressões realizadas, conforme Tabela 3, observa-se pela coluna (2) de efeitos aleatórios que apenas a variável relacionada à estrutura de propriedade é estatisticamente significativa.

Diferentemente daquilo encontrado para a remuneração fixa do conselho de administração e da própria literatura mencionada neste trabalho, essa variável, que é o percentual votante do maior acionista, está positivamente correlacionada com remuneração variável do conselho, ou seja, quanto maior a concentração de ações maior a remuneração variável do conselho.

Apesar dessa relevância estatística, importante ressaltar que há poucas observações para a variável remuneração variável, conforme explicado anteriormente. Além disso, há no mercado acionário brasileiro muitos acionistas controladores que participam do conselho de administração da companhia, podendo ser uma explicação para a correlação positiva dessa variável. Uma alternativa, seria incluir variáveis no modelo para controlar conselhos que possuem integrantes que são ao mesmo tempo controladores da companhia. Essa análise pode ser realizada em trabalhos futuros sobre o assunto.

\subsection{Remuneração em ações do conselho de administração}

O mesmo destaque feito no item anterior, sobre remuneração variável do conselho, vale para este item, que trata da remuneração em ações do conselho. Em função da remuneração paga aos membros do conselho de administração ser em grande parte composta por parcela fixa, há poucos registros e, consequentemente, poucas observações a serem utilizadas nas regressões para a parcela em ações da remuneração do conselho.

De acordo com a

Tabela 4, é possível observar que há menos de 110 registros de companhias que pagaram seus conselheiros utilizando-se de remuneração em ações, durante o período de 2010 a 2014. Para as regressões com a remuneração fixa como variável dependente, por exemplo, foram encontrados entre 1020 e 1322 observações para o mesmo período. 


\section{Tabela 4 - Regressão: In natural de AP}

Variável dependente: logaritmo natural da remuneração em ações do conselho de administração

\begin{tabular}{|c|c|c|}
\hline Regressão por Painel: & \multicolumn{2}{|c|}{ efeitos fixos } \\
\hline Variáveis & (1) & (2) \\
\hline $\begin{array}{l}\text { CQ } \\
\% \text { ROA }\end{array}$ & $\begin{array}{l}0.006 * * \\
(2.256)\end{array}$ & $\begin{array}{c}0.019 \\
(1.281)\end{array}$ \\
\hline $\begin{array}{l}\text { CR } \\
\% \text { ROA defasado_1 ano }\end{array}$ & $\begin{array}{c}0.002 \\
(0.045)\end{array}$ & $\begin{array}{c}0.029 \\
(0.525)\end{array}$ \\
\hline $\begin{array}{l}\text { CY1 } \\
\text { \% ROA defasado_2 anos }\end{array}$ & $\begin{array}{c}0.038 \\
(1.272)\end{array}$ & $\begin{array}{c}0.026 \\
(0.836)\end{array}$ \\
\hline $\begin{array}{l}\ln (\mathbf{C L}) \\
\ln (\text { ativo total) }\end{array}$ & $\begin{array}{c}0.203 \\
(0.348)\end{array}$ & $\begin{array}{c}0.979 \\
(0.743) \\
\end{array}$ \\
\hline M - dummy - segmento de listagem & & $\begin{array}{c}1.622 * * * \\
(3.161)\end{array}$ \\
\hline BX - \% votante do maior acionista & & $\begin{array}{c}0.011 \\
(0.834)\end{array}$ \\
\hline $\begin{array}{l}\text { AA } \\
n^{\circ} \text { membros do CA }\end{array}$ & & $\begin{array}{c}0.243 \\
(1.547)\end{array}$ \\
\hline $\begin{array}{l}\text { AS } \\
n^{\circ} \text { membros da Dir. }\end{array}$ & & $\begin{array}{c}0.263 \\
(1.338) \\
\end{array}$ \\
\hline $\begin{array}{l}\text { CO } \\
\text { LPA (lucro por ação) }\end{array}$ & & $\begin{array}{c}-0.031 \\
(-1.541)\end{array}$ \\
\hline $\begin{array}{l}\text { DA } \\
\text { retorno ação }\end{array}$ & & $\begin{array}{l}0.015 * * * \\
(3.541)\end{array}$ \\
\hline $\begin{array}{l}\text { DTT } \\
\text { retorno ação_1 ano }\end{array}$ & & $\begin{array}{c}0.002 \\
(1.581) \\
\end{array}$ \\
\hline $\mathbf{R}^{2}$ within & 0.13 & 0.34 \\
\hline $\mathbf{R}^{2}$ overall & 0.15 & 0.10 \\
\hline Obs. & 107 & 92 \\
\hline Teste de hausman (p-valor) & erro & erro \\
\hline
\end{tabular}

efeitos aleatórios

\begin{tabular}{|c|c|}
\hline $\mathbf{( 1 )}$ & $\mathbf{( 2 )}$ \\
\hline $0.003^{* *}$ & -0.007 \\
$(1.983)$ & $(-0.343)$ \\
\hline 0.035 & 0.036 \\
$(1.027)$ & $(0.857)$ \\
\hline 0.006 & 0.002 \\
$(0.184)$ & $(0.068)$ \\
\hline $0.448^{* * *}$ & 0.177 \\
$(3.654)$ & $(0.878)$ \\
\hline & -1.278 \\
& $(-1.292)$ \\
\hline & -0.001 \\
& $(-0.114)$ \\
\hline & $0.186 *$ \\
& $(1.958)$ \\
\hline & $-0.036^{* *}$ \\
$(-2.132)$ \\
\hline & 0.012 \\
& $(0.342)$ \\
\hline & $0.010^{* *}$ \\
& $(2.243)$ \\
\hline & 0.002 \\
& $(1.191)$ \\
\hline & \\
\hline 0.11 & 0.17 \\
\hline & \\
\hline 107 & 92 \\
\hline & \\
\hline
\end{tabular}

A variável dependente é representada pela remuneração baseada em ações paga a todos os membros do conselho de administração. As variáveis CQ, CR e CY1 medem o desempenho operacional, com as duas últimas sendo variáveis com 1 e 2 anos de defasagem, respectivamente. Tamanho da firma está representa pela variável ln (CL). A variável dummy M indica se determinada companhia está (1) ou não está (0) nos segmentes de listagem Novo Mercado e Nível 2. A variável BX representa o percentual do capital votante do acionista com mais ações ON no período. As variáveis AA e AS representam, respectivamente, o número de membros do Conselho de Administração e da Diretoria das sociedades. A variável CO representa o lucro por ação. As variáveis DA e DTT representam o retorno da ação mais negociada da companhia, sendo a DTT com 1 ano de defasagem. A regressão contém variáveis dummies de ano (2011 a 2014). A estatística t está indicada em parênteses. $* * *, * *, *$ indicam as significâncias aos níveis de $1 \%, 5 \%$ e $10 \%$, respectivamente. 


\subsubsection{Variáveis de desempenho}

Apenas a varável de desempenho operacional com dados contemporâneos apresentou significância nas regressões realizadas. E apenas foi significativa quando não incluídas a maioria das variáveis de controle. Pela coluna (1) da

Tabela 4, um aumento de $10 \%$ no resultado operacional da companhia aumenta em $6 \%$ a remuneração em ações do conselho. Quando incluída variáveis de controle, nenhuma variável de desempenho (contemporânea, 1 e 2 anos defasadas) apresentou relevância estatística.

\subsubsection{Variáveis de controle}

Ao adicionar variáveis de controle nas regressões realizadas, conforme

Tabela 4, observa-se pela coluna (2) de efeitos aleatórios que poucas variáveis são significativas. Cabe destacar que para cada membro adicional no conselho, a remuneração em ações aumenta em 18,6\%. Já em relação à variável nº de membros da diretoria, há correlação negativa entre tamanho da diretoria e remuneração em ações do conselho. Ressalta-se que a análise sobre se o aumento de um conselheiro de administração aumenta a remuneração média do conselho como um todo será feita apenas para a remuneração total do conselho (item 4.5), considerando as parcelas fixa, variável, entre outras existentes.

Outra variável positivamente correlacionada com a remuneração em ações é a DA (retorno da ação). Aumento de $10 \%$ no retorno da ação no ano, aumenta em $10 \%$ a remuneração em ações.

\subsection{Remuneração total do conselho de administração}

Na remuneração total do conselho estão incluídas as remunerações fixa, variável, por ação, bônus e qualquer outro benefício financeiro recebido pelos membros do conselho de administração ao longo dos exercícios financeiro analisados. 


\subsubsection{Variáveis de desempenho}

As regressões são apresentadas na Tabela 5. Considerando um nível de significância de 5\%, as variáveis de desempenho não são estatisticamente significantes, ou seja, não há evidência estatísticas de relação entre remuneração total do conselho e desempenho operacional da companhia, seja usando dados contemporâneos, seja usando dados defasados de 1 e 2 anos, utilizando o método de efeitos fixos.

Por efeitos aleatórios, as variáveis defasadas na coluna (1) são significativas e relacionadas positivamente com a remuneração total, entretanto, os coeficientes são inexpressivos. Os coeficientes de ROA_1 e ROA_2 indicam que um aumento de 10\% no desempenho da companhia leva a um aumento na remuneração total do conselho de menos de $0,5 \%$.

\section{Tabela 5 - Regressão: In natural de AR}

Variável dependente: logaritmo natural da remuneração total do conselho de administração

\begin{tabular}{|c|c|c|}
\hline Regressão por Painel: & \multicolumn{2}{|c|}{ efeitos fixos } \\
\hline Variáveis & (1) & (2) \\
\hline $\begin{array}{l}\text { CQ } \\
\% \text { ROA }\end{array}$ & $\begin{array}{c}-0.000 \\
(-0.080) \\
\end{array}$ & $\begin{array}{l}-0.002 * \\
(-1.654) \\
\end{array}$ \\
\hline $\begin{array}{l}\text { CR } \\
\% \text { ROA defasado_1 ano }\end{array}$ & $\begin{array}{l}0.000 * \\
(1.917) \\
\end{array}$ & $\begin{array}{c}0.002 \\
(1.310) \\
\end{array}$ \\
\hline $\begin{array}{l}\text { CY1 } \\
\text { \% ROA defasado_2 anos }\end{array}$ & $\begin{array}{c}0.000 \\
(1.567)\end{array}$ & $\begin{array}{c}-0.000 \\
(-0.198)\end{array}$ \\
\hline $\begin{array}{l}\ln (\mathbf{C L}) \\
\ln (\text { ativo total) }\end{array}$ & $\begin{array}{l}0.218 * * \\
(2.354)\end{array}$ & $\begin{array}{c}0.344 * * * \\
(3.650)\end{array}$ \\
\hline M - dummy - segmento de listagem & & $\begin{array}{c}0.323 \\
(1.295)\end{array}$ \\
\hline BX - \% votante do maior acionista & & $\begin{array}{c}0.001 \\
(0.494)\end{array}$ \\
\hline $\begin{array}{l}\text { AA } \\
n^{\circ} \text { membros do CA }\end{array}$ & & $\begin{array}{c}0.088 * * * \\
(2.848)\end{array}$ \\
\hline $\begin{array}{l}\text { AS } \\
n^{\circ} \text { membros da Dir. }\end{array}$ & & $\begin{array}{c}0.019 \\
(0.772)\end{array}$ \\
\hline $\begin{array}{l}\text { CO } \\
\text { LPA (lucro por ação) }\end{array}$ & & $\begin{array}{c}-0.000 \\
(-0.014) \\
\end{array}$ \\
\hline $\begin{array}{l}\text { DA } \\
\text { retorno ação }\end{array}$ & & $\begin{array}{c}0.001 \\
(1.539)\end{array}$ \\
\hline $\begin{array}{l}\text { DTT } \\
\text { retorno ação_1 ano }\end{array}$ & & $\begin{array}{c}0.001 \\
(1.600) \\
\end{array}$ \\
\hline $\mathbf{R}^{2}$ within & 0.15 & 0.18 \\
\hline
\end{tabular}

\begin{tabular}{|c|c|}
\hline (1) & (2) \\
\hline $\begin{array}{c}-0.000 \\
(-0.436)\end{array}$ & $\begin{array}{c}-0.002 \\
(-1.447)\end{array}$ \\
\hline $\begin{array}{c}0.000^{* *} \\
(2.219)\end{array}$ & $\begin{array}{c}0.002 \\
(1.511)\end{array}$ \\
\hline $\begin{array}{c}0.000 * * \\
(2.024)\end{array}$ & $\begin{array}{c}-0.000 \\
(-0.084)\end{array}$ \\
\hline \multirow[t]{8}{*}{$\begin{array}{c}0.301 * * * \\
(7.555) \\
\end{array}$} & $\begin{array}{c}0.236 * * * \\
(5.582)\end{array}$ \\
\hline & $\begin{array}{c}0.275 * * \\
(2.118)\end{array}$ \\
\hline & $\begin{array}{c}-0.002 \\
(-0.835) \\
\end{array}$ \\
\hline & $\begin{array}{c}0.080 * * * \\
(3.415)\end{array}$ \\
\hline & $\begin{array}{l}0.023^{*} \\
(1.794)\end{array}$ \\
\hline & $\begin{array}{c}-0.000 \\
(-0.183)\end{array}$ \\
\hline & $\begin{array}{c}0.001 \\
(1.624)\end{array}$ \\
\hline & $\begin{array}{c}0.001 \\
(1.624)\end{array}$ \\
\hline 0.15 & 0.17 \\
\hline
\end{tabular}




\begin{tabular}{|c|c|c|c|c|}
\hline $\mathbf{R}^{2}$ overall & 0.21 & 0.24 & & \\
\hline Obs. & 1343 & 1039 & 1343 & 1039 \\
\hline Teste de hausman (p-valor) & 0.2807 & 0.7794 & & \\
\hline
\end{tabular}

A variável dependente é representada pela remuneração total (fixa + variável + ações + outras) paga a todos os membros do conselho de administração. As variáveis CQ, CR e CY1 medem o desempenho operacional, com as duas últimas sendo variáveis com 1 e 2 anos de defasagem, respectivamente. Tamanho da firma está representa pela variável ln (CL). A variável dummy M indica se determinada companhia está (1) ou não está (0) nos segmentes de listagem Novo Mercado e Nível 2. A variável BX representa o percentual do capital votante do acionista com mais ações ON no período. As variáveis AA e AS representam, respectivamente, o número de membros do Conselho de Administração e da Diretoria das sociedades. A variável CO representa o lucro por ação. As variáveis DA e DTT representam o retorno da ação mais negociada da companhia, sendo a DTT com 1 ano de defasagem. A regressão contém variáveis dummies de ano (2011 a 2014). A estatística t está indicada em parênteses. ***, **, * indicam as significâncias aos níveis de $1 \%, 5 \%$ e $10 \%$, respectivamente.

\subsubsection{Variáveis de controle}

Assim como no item analisado para remuneração fixa do conselho, a variável que representa o tamanho da empresa neste modelo, logaritmo natural do ativo total - $\ln$ (CL), foi estatisticamente significativa em todas as regressões realizadas, tanto pelo método de efeitos fixos quanto por efeitos aleatórios. Em média, pelo método de efeitos aleatórios, um aumento de $10 \%$ no tamanho da companhia aumenta em 2,5\% a remuneração fixa do conselho.

A variável de controle utilizada como correspondente à estrutura de propriedade da companhia (BX) não foi estatisticamente significativa em nenhuma das regressões utilizadas. Já a variável dummy M apresentou forte relação positiva com remuneração total do conselho. A variável é igual a 1 se a companhia está listada nos segmentos da BM\&FBOVESPA de maior nível de governança corporativa e transparência (novo mercado e nível 2) e igual a 0 se não estiver listada nesse segmento. Conselhos de companhias listadas em segmentos de elevada governança recebem, conforme coluna (2), 27,5\% a mais que companhias não listadas nesses segmentos.

Assim como na análise realizada para a remuneração fixa do conselho, verificou-se também aqui forte correlação positiva entre remuneração total do conselho e quantidade de membros que compõem este conselho. Também há relação positiva e significância estatística a $10 \%$ entre remuneração total e $n^{\circ}$ de membros da diretoria da companhia.

As variáveis que representam o retorno da ação da companhia nos últimos 12 meses, contemporânea e defasada em 1 ano, não apresentaram resultados significativos, assim como a variável CO. 


\subsection{Remuneração média por conselheiro}

Alguns destaques são importantes fazer quando utilizamos remuneração média em vez de remuneração total, conforme item anterior, para a variável dependente. Entre eles é que a variável de desempenho com 2 anos de defasagem passa a ser estatisticamente significante e positivamente correlacionado com remuneração média por conselheiro, mas apenas na coluna (1) da

Tabela 6. Entretanto, os coeficientes são extremamente baixos. O coeficiente de ROA_2 indica que um aumento de $10 \%$ no desempenho da companhia leva a um aumento na remuneração total do conselho em menos de $0,5 \%$.

Em relação às variáveis de controle, verifica-se que a variável que representa o ${ }^{\circ}$ de membros do conselho de administração apresenta relação negativa com a remuneração média por conselheiro. Com isso, embora em boa parte das regressões anteriores tenha sido encontrada relação positiva e significativa entre tamanho do conselho e remuneração, pela regressão da Tabela 6 verifica-se que o aumento de conselheiro não aumenta a remuneração média do colegiado, pelo contrário, há evidência que quanto maior o conselho, menor será a remuneração média por conselheiro. Assim, tem-se que o montante total pago ao conselho em forma de remuneração aumenta com a adição de novos membros, porém, a remuneração média por conselheiro é reduzida.

Já a variável que representa o tamanho da diretoria da companhia, apresenta a mesma interpretação da regressão anteriormente realizada, com a remuneração total do conselho. Com isso, há evidências, a $10 \%$ de significância, que quanto maior $\mathrm{o} \mathrm{n}^{\circ}$ de diretores nas companhias maior será a remuneração total do conselho de administração e maior será a remuneração média por conselheiro.

\section{Tabela 6 - Regressão: In natural de AV2}

Variável dependente: logaritmo natural da remuneração média por conselheiro de administração

Regressão por Painel:

\begin{tabular}{|l|c|c|}
\hline Variáveis & $(\mathbf{1})$ & $\mathbf{( 2 )}$ \\
\hline CQ & 0.000 & -0.002 \\
\% ROA & $(0.304)$ & $(-1.607)$ \\
\hline CR & 0.000 & 0.002 \\
\% ROA defasado_1 ano & $(1.533)$ & $(1.263)$ \\
\hline CY1 & $0.000 * * *$ & -0.000 \\
\hline
\end{tabular}

efeitos aleatórios

\begin{tabular}{|c|c|}
\hline $\mathbf{( 1 )}$ & $(\mathbf{2})$ \\
\hline 0.000 & -0.002 \\
$(0.097)$ & $(-1.394)$ \\
\hline 0.000 & 0.002 \\
$(1.598)$ & $(1.487)$ \\
\hline $0.000 * * *$ & -0.000 \\
\hline
\end{tabular}




\begin{tabular}{|l|c|c|}
\hline \% ROA defasado_2 anos & $(2.740)$ & $(-0.162)$ \\
\hline In (CL) & 0.137 & $0.365^{* * *}$ \\
ln (ativo total) & $(1.642)$ & $(3.699)$ \\
\hline M - dummy - segmento de listagem & & 0.273 \\
& $(1.133)$ \\
\hline BX - \% votante do maior acionista & & 0.001 \\
& $0.521)$ \\
\hline AA & & $-0.076^{*}$ \\
$\mathrm{n}^{\mathbf{o}}$ membros do CA & & $(-1.794)$ \\
\hline AS & & 0.024 \\
$\mathrm{n}^{\mathbf{o}}$ membros da Dir. & & $(1.010)$ \\
\hline CO & & -0.000 \\
LPA (lucro por ação) & & $0.224)$ \\
\hline DA & & $(1.591)$ \\
\hline retorno ação & & $0.001 *$ \\
\hline DTT & & \\
retorno ação_1 ano & & \\
\hline & & 0.137 \\
\hline $\mathbf{R}^{2}$ within & 0.12 & 0.16 \\
\hline $\mathbf{R}^{2}$ overall & 1343 & 1039 \\
\hline Obs. & 0.7874 & 0.1631 \\
\hline Teste de hausman (p-valor)
\end{tabular}

\begin{tabular}{|c|c|}
\hline$(3.985)$ & $(-0.081)$ \\
\hline $0.204^{* * *}$ & $\begin{array}{c}0.244^{* * *} \\
(5.501)\end{array}$ \\
\hline & $\begin{array}{c}0.214^{*} \\
(1.653)\end{array}$ \\
\hline & $\begin{array}{c}-0.002 \\
(-0.888)\end{array}$ \\
\hline & $\begin{array}{c}-0.071^{* *} \\
(-2.442)\end{array}$ \\
\hline & $\begin{array}{c}0.022^{*} \\
(1.868)\end{array}$ \\
\hline & $\begin{array}{c}-0.000 \\
(-0.386)\end{array}$ \\
\hline & $0.001^{*}$ \\
& $(1.713)$ \\
\hline & $0.001^{*}$ \\
& $(1.700)$ \\
\hline & \\
\hline 0.10 & 0.13 \\
\hline 1343 & 0.17 \\
\hline & 1039 \\
\hline
\end{tabular}

A variável dependente é representada pela remuneração média paga a todos os membros do conselho de administração. As variáveis CQ, CR e CY1 medem o desempenho operacional, com as duas últimas sendo variáveis com 1 e 2 anos de defasagem, respectivamente. Tamanho da firma está representa pela variável ln (CL). A variável dummy M indica se determinada companhia está (1) ou não está (0) nos segmentes de listagem Novo Mercado e Nível 2. A variável BX representa o percentual do capital votante do acionista com mais ações ON no período. As variáveis AA e AS representam, respectivamente, o número de membros do Conselho de Administração e da Diretoria das sociedades. A variável CO representa o lucro por ação. As variáveis DA e DTT representam o retorno da ação mais negociada da companhia, sendo a DTT com 1 ano de defasagem. A regressão contém variáveis dummies de ano (2011 a 2014). A estatística t está indicada em parênteses. $* * *, * * *$ indicam as significâncias aos níveis de $1 \%, 5 \%$ e $10 \%$, respectivamente.

\subsection{Maior e menor remuneração do conselho de administração}

\subsubsection{Variáveis de desempenho}

Nas Tabela 7 e Tabela 8, encontram-se as regressões utilizando como variável dependente a maior e a menor remuneração recebida no conselho de administração. Não se verificou significância estatística entre desempenho operacional da companhia e menor remuneração do conselho, pelo método efeitos fixos. E apenas a variável de desempenho com 1 ano de defasagem, ROA_1, na coluna (2), apresentou correlação significativa e positiva com a maior remuneração recebido no conselho; para um aumento em 10\% no ROA_1 aumenta em $3 \%$ a maior remuneração recebida. 


\section{Tabela 7 - Regressão: In natural de BS}

Variável dependente: logaritmo natural da menor remuneração total do conselho de administração

\begin{tabular}{|c|c|c|}
\hline Regressão por Painel: & \multicolumn{2}{|c|}{ efeitos fixos } \\
\hline Variáveis & (1) & (2) \\
\hline $\begin{array}{l}\text { CQ } \\
\% \text { ROA }\end{array}$ & $\begin{array}{c}-0.000 \\
(-0.359) \\
\end{array}$ & $\begin{array}{c}-0.001 \\
(-0.289) \\
\end{array}$ \\
\hline $\begin{array}{l}\text { CR } \\
\% \text { ROA defasado_1 ano }\end{array}$ & $\begin{array}{c}0.000 \\
(0.859)\end{array}$ & $\begin{array}{c}0.002 \\
(1.071)\end{array}$ \\
\hline $\begin{array}{l}\text { CY1 } \\
\text { \% ROA defasado_2 anos }\end{array}$ & $\begin{array}{c}-0.000 \\
(-1.519) \\
\end{array}$ & $\begin{array}{c}-0.000 \\
(-0.215)\end{array}$ \\
\hline $\begin{array}{l}\ln (\mathbf{C L}) \\
\ln (\text { ativo total })\end{array}$ & $\begin{array}{l}0.193 * \\
(1.671) \\
\end{array}$ & $\begin{array}{l}0.354 * * \\
(2.577)\end{array}$ \\
\hline M - dummy - segmento de listagem & & $\begin{array}{c}- \\
0.193 * * * \\
(-2.678)\end{array}$ \\
\hline $\mathbf{B X}$ - \% votante do maior acionista & & $\begin{array}{l}-0.006^{*} \\
(-1.742) \\
\end{array}$ \\
\hline $\begin{array}{l}\mathbf{A A} \\
n^{\circ} \text { membros do CA }\end{array}$ & & $\begin{array}{c}0.001 \\
(0.029) \\
\end{array}$ \\
\hline $\begin{array}{l}\text { AS } \\
n^{\circ} \text { membros da Dir. }\end{array}$ & & $\begin{array}{c}-0.004 \\
(-0.276) \\
\end{array}$ \\
\hline $\begin{array}{l}\text { CO } \\
\text { LPA (lucro por ação) }\end{array}$ & & $\begin{array}{c}0.000 \\
(0.923) \\
\end{array}$ \\
\hline $\begin{array}{l}\text { DA } \\
\text { retorno ação }\end{array}$ & & $\begin{array}{c}0.000 \\
(0.279) \\
\end{array}$ \\
\hline $\begin{array}{l}\text { DTT } \\
\text { retorno ação_1 ano }\end{array}$ & & $\begin{array}{c}0.001 \\
(1.626) \\
\end{array}$ \\
\hline $\mathbf{R}^{2}$ within & 0.10 & 0.12 \\
\hline $\mathbf{R}^{2}$ overall & 0.12 & 0.13 \\
\hline Obs. & 1017 & 802 \\
\hline Teste de hausman (p-valor) & 0.5594 & 0.8670 \\
\hline
\end{tabular}

efeitos aleatórios

\begin{tabular}{|c|c|}
\hline (1) & (2) \\
\hline $\begin{array}{c}0.000 \\
(0.204)\end{array}$ & $\begin{array}{c}0.000 \\
(0.120)\end{array}$ \\
\hline $\begin{array}{c}0.000 \\
(0.916)\end{array}$ & $\begin{array}{c}0.002 \\
(1.337)\end{array}$ \\
\hline $\begin{array}{c}-0.000 \\
(-0.594)\end{array}$ & $\begin{array}{c}0.000 \\
(0.045)\end{array}$ \\
\hline \multirow[t]{8}{*}{$\begin{array}{c}0.218 * * * \\
(5.231)\end{array}$} & $\begin{array}{c}0.199 * * * \\
(4.426)\end{array}$ \\
\hline & $\begin{array}{c}0.492 * * * \\
(3.347)\end{array}$ \\
\hline & $\begin{array}{c}-0.009 * * * \\
(-3.783)\end{array}$ \\
\hline & $\begin{array}{c}-0.012 \\
(-0.629)\end{array}$ \\
\hline & $\begin{array}{c}-0.008 \\
(-0.778)\end{array}$ \\
\hline & $\begin{array}{c}0.000 \\
(0.276)\end{array}$ \\
\hline & $\begin{array}{c}0.000 \\
(0.162)\end{array}$ \\
\hline & $\begin{array}{c}0.001 \\
(1.605) \\
\end{array}$ \\
\hline 0.10 & 0.11 \\
\hline 0.12 & 0.25 \\
\hline 1017 & 802 \\
\hline
\end{tabular}

A variável dependente é representada pela menor remuneração paga entre os membros do conselho de administração. As variáveis CQ, CR e CY1 medem o desempenho operacional, com as duas últimas sendo variáveis com 1 e 2 anos de defasagem, respectivamente. Tamanho da firma está representa pela variável ln (CL). A variável dummy M indica se determinada companhia está (1) ou não está (0) nos segmentes de listagem Novo Mercado e Nível 2. A variável BX representa o percentual do capital votante do acionista com mais ações ON no período. As variáveis AA e AS representam, respectivamente, o número de membros do Conselho de Administração e da Diretoria das sociedades. A variável CO representa o lucro por ação. As variáveis DA e DTT representam o retorno da ação mais negociada da companhia, sendo a DTT com 1 ano de defasagem. A regressão contém variáveis dummies de ano (2011 a 2014). A estatística t está indicada em parênteses. $* * *, * * *$ indicam as significâncias aos níveis de $1 \%, 5 \%$ e $10 \%$, respectivamente.

\section{Tabela 8 - Regressão: In natural de BR}

Variável dependente: logaritmo natural da maior remuneração total do conselho de administração

\begin{tabular}{|l|c|c|}
\multicolumn{1}{c}{ Regressão por Painel: } & \multicolumn{2}{c|}{ efeitos fixos } \\
\hline Variáveis & $\mathbf{( 1 )}$ & $\mathbf{( 3 )}$ \\
\hline CQ & 0.001 & 0.003 \\
\% ROA & $(0.984)$ & $(1.567)$ \\
\hline CR & 0.000 & $0.003^{* *}$ \\
\% ROA defasado_1 ano & $(1.523)$ & $(2.084)$ \\
\hline
\end{tabular}

\begin{tabular}{|} 
efeitos aleatórios \\
\hline $\mathbf{( 1 )}$ & $\mathbf{( 3 )}$ \\
\hline 0.001 & 0.002 \\
$(1.388)$ & $(1.525)$ \\
\hline $0.000^{* * *}$ & $0.002^{* *}$ \\
$(2.584)$ & $(2.219)$ \\
\hline
\end{tabular}




\begin{tabular}{|c|c|c|}
\hline $\begin{array}{l}\text { CY1 } \\
\text { \% ROA defasado_2 anos }\end{array}$ & $\begin{array}{c}-0.000 \\
(-0.912) \\
\end{array}$ & $\begin{array}{c}0.002 \\
(1.284)\end{array}$ \\
\hline $\begin{array}{l}\ln (\mathbf{C L}) \\
\ln (\text { ativo total) }\end{array}$ & $\begin{array}{c}0.255 * * * \\
(2.632)\end{array}$ & $\begin{array}{l}0.434 * * * \\
(2.705)\end{array}$ \\
\hline M - dummy - segmento de listagem & & $\begin{array}{c}-0.058 \\
(-0.176) \\
\end{array}$ \\
\hline $\mathbf{B X}$ - \% votante do maior acionista & & $\begin{array}{c}0.002 \\
(0.445)\end{array}$ \\
\hline $\begin{array}{l}\mathbf{A A} \\
\mathrm{n}^{\circ} \text { membros do CA }\end{array}$ & & $\begin{array}{c}-0.029 \\
(-0.798)\end{array}$ \\
\hline $\begin{array}{l}\text { AS } \\
n^{\circ} \text { membros da Dir. }\end{array}$ & & $\begin{array}{c}0.040 \\
(1.146)\end{array}$ \\
\hline $\begin{array}{l}\text { CO } \\
\text { LPA (lucro por ação) }\end{array}$ & & $\begin{array}{c}-0.000 \\
(-0.689) \\
\end{array}$ \\
\hline $\begin{array}{l}\text { DA } \\
\text { retorno ação }\end{array}$ & & $\begin{array}{c}0.002 \\
(1.326)\end{array}$ \\
\hline $\begin{array}{l}\text { DTT } \\
\text { retorno ação_1 ano }\end{array}$ & & $\begin{array}{c}0.001 \\
(1.541)\end{array}$ \\
\hline $\mathbf{R}^{2}$ within & 0.13 & 0.15 \\
\hline $\mathbf{R}^{2}$ overall & 0.11 & 0.09 \\
\hline Obs. & 1045 & 824 \\
\hline Teste de hausman (p-valor) & 0.8463 & 0.2596 \\
\hline
\end{tabular}

\begin{tabular}{|c|c|}
\hline $\begin{array}{c}-0.000 \\
(-0.829)\end{array}$ & $\begin{array}{c}0.001 \\
(0.752)\end{array}$ \\
\hline $0.261^{* * *}$ & $0.220^{* * *}$ \\
$(5.451)$ & $(3.255)$ \\
\hline & $\begin{array}{c}0.451^{* *} \\
(2.460)\end{array}$ \\
\hline & $\begin{array}{c}-0.005^{*} \\
(-1.684)\end{array}$ \\
\hline & -0.030 \\
& $(-1.128)$ \\
\hline & 0.010 \\
& $(0.384)$ \\
\hline & -0.000 \\
& $(-0.726)$ \\
\hline & 0.002 \\
& $(1.345)$ \\
\hline & 0.001 \\
& $(1.492)$ \\
\hline 0.13 & 0.13 \\
\hline 0.11 & 0.18 \\
\hline 1045 & 824 \\
\hline & \\
\hline
\end{tabular}

A variável dependente é representada pela maior remuneração paga entre os membros do conselho de administração. As variáveis CQ, CR e CY1 medem o desempenho operacional, com as duas últimas sendo variáveis com 1 e 2 anos de defasagem, respectivamente. Tamanho da firma está representa pela variável ln (CL). A variável dummy $\mathrm{M}$ indica se determinada companhia está (1) ou não está (0) nos segmentes de listagem Novo Mercado e Nível 2. A variável BX representa o percentual do capital votante do acionista com mais ações ON no período. As variáveis AA e AS representam, respectivamente, o número de membros do Conselho de Administração e da Diretoria das sociedades. A variável CO representa o lucro por ação. As variáveis DA e DTT representam o retorno da ação mais negociada da companhia, sendo a DTT com 1 ano de defasagem. A regressão contém variáveis dummies de ano (2011 a 2014). A estatística t está indicada em parênteses. $* * *, * *, *$ indicam as significâncias aos níveis de $1 \%, 5 \%$ e $10 \%$, respectivamente.

\subsubsection{Variáveis de controle}

Diferentemente do encontrado nos itens anteriores, a quantidade de membros no conselho de administração e na diretoria não impactam a maior nem a menor remuneração recebida no conselho. Já as variáveis de estrutura de propriedade e de segmento de listagem apresentam-se estatisticamente significantes, em todas as regressões, indicando que companhias com controle minoritário pagam mais aos conselheiros e companhias listadas em níveis de elevada governança remuneram melhor seus conselheiros, tanto o de maior quanto o de menor remuneração, comparado com companhias que não estão nesses segmentos. 


\subsection{Remuneração fixa da diretoria}

\subsubsection{Variáveis de desempenho}

Na regressão utilizando o método de efeitos fixos, as variáveis de desempenho defasadas, ROA_1 e ROA_2, apresentaram significância estatística na regressão apresentada na coluna (1) da Tabela 9. Os coeficientes dessas variáveis indicam que há correlação negativa entre desempenho operacional da companhia e remuneração fixa da diretoria, entretanto, são extremamente baixos, indicando que variações em $10 \%$ no desempenho da companhia alteram em menos de $0,5 \%$ a remuneração fixa total da diretoria.

Ou seja, apesar de serem estatisticamente significativas, as variáveis de desempenho impactam muito pouco a remuneração fixa da diretoria. Quando incluímos variáveis de controle nas regressões, coluna (2) da regressão por efeitos fixos, as variáveis de desempenho passam a não ser estatisticamente significantes.

Tabela 9 - Regressão: In natural de AX

Variável dependente: logaritmo natural da remuneração fixa da diretoria

\begin{tabular}{|l|c|c|}
\multicolumn{1}{|c}{ Regressão por Painel: } & $(\mathbf{2})$ \\
\hline Variáveis & & \\
\hline CQ & 0.000 & 0.000 \\
$\%$ ROA & $(0.431)$ & $(0.302)$ \\
\hline CR & $-0.000^{* * *}$ & 0.001 \\
\% ROA defasado_1 ano & $(-3.351)$ & $(0.867)$ \\
\hline CY1 & $-0.000^{* * *}$ & 0.000 \\
\% ROA defasado_2 anos & $(-3.574)$ & $(0.016)$ \\
\hline In (CL) & $0.181^{* *}$ & $0.267 * * *$ \\
ln (ativo total) & $(2.093)$ & $(4.585)$ \\
\hline M - dummy - segmento de listagem & & -0.069 \\
& & $(-0.643)$ \\
\hline BX - \% votante do maior acionista & & -0.001 \\
& & $(-0.755)$ \\
\hline AA & & 0.016 \\
$\mathrm{n}^{\circ}$ membros do CA & & $(0.966)$ \\
\hline AS & & $0.076^{* * *}$ \\
$\mathrm{n}^{\circ}$ membros da Dir. & & $(4.458)$ \\
\hline CO & & $0.000^{* *}$ \\
LPA (lucro por ação) & & 0.000 \\
\hline DA \\
retorno ação & & $(0.261)$ \\
\hline DTT & & 0.000 \\
\hline
\end{tabular}

\begin{tabular}{|c|c|}
\hline (1) & (2) \\
\hline $\begin{array}{c}-0.000 \\
(-0.117)\end{array}$ & $\begin{array}{c}0.001 \\
(0.976)\end{array}$ \\
\hline $\begin{array}{c}-0.000 * * * \\
(-3.922)\end{array}$ & $\begin{array}{l}0.002 * * \\
(2.205)\end{array}$ \\
\hline $\begin{array}{c}-0.000 * * * \\
(-5.753)\end{array}$ & $\begin{array}{c}-0.000 \\
(-0.023)\end{array}$ \\
\hline \multirow[t]{8}{*}{$\begin{array}{c}0.324 * * * \\
(6.973) \\
\end{array}$} & $\begin{array}{c}0.222 * * * \\
(5.847)\end{array}$ \\
\hline & $\begin{array}{c}0.237 * * \\
(2.301)\end{array}$ \\
\hline & $\begin{array}{r}-0.003 * * \\
(-2.188) \\
\end{array}$ \\
\hline & $\begin{array}{c}0.019 \\
(1.493)\end{array}$ \\
\hline & $\begin{array}{c}0.058 * * * \\
(4.727)\end{array}$ \\
\hline & $\begin{array}{c}0.000 * * * \\
(3.564)\end{array}$ \\
\hline & $\begin{array}{c}0.000 \\
(0.438)\end{array}$ \\
\hline & 0.000 \\
\hline
\end{tabular}




\begin{tabular}{|l|c|c|}
\hline retorno ação_1 ano & & $(0.444)$ \\
\hline & & \\
\hline $\mathbf{R}^{2}$ within & 0.20 & 0.28 \\
\hline $\mathbf{R}^{\mathbf{2}}$ overall & 0.38 & 0.40 \\
\hline Obs. & 1350 & 1057 \\
\hline Teste de hausman (p-valor) & 0.0003 & 0.1851 \\
\hline
\end{tabular}

\begin{tabular}{|l|l|}
\hline & $(0.609)$ \\
\hline & \\
\hline 0.19 & 0.28 \\
\hline 0.38 & 0.45 \\
\hline 1350 & 1057 \\
\hline & \\
\hline
\end{tabular}

A variável dependente é representada pela remuneração fixa (salário, benefícios diretos e indiretos, participação em comitês e outros pagamentos fixos) paga a todos os membros da diretoria. As variáveis CQ, CR e CY1 medem o desempenho operacional, com as duas últimas sendo variáveis com 1 e 2 anos de defasagem, respectivamente. Tamanho da firma está representa pela variável ln (CL). A variável dummy $\mathrm{M}$ indica se determinada companhia está (1) ou não está (0) nos segmentes de listagem Novo Mercado e Nível 2. A variável BX representa o percentual do capital votante do acionista com mais ações ON no período. As variáveis AA e AS representam, respectivamente, o número de membros do Conselho de Administração e da Diretoria das sociedades. A variável CO representa o lucro por ação. As variáveis DA e DTT representam o retorno da ação mais negociada da companhia, sendo a DTT com 1 ano de defasagem. A regressão contém variáveis dummies de ano (2011 a 2014). A estatística t está indicada em parênteses. ***,**, * indicam as significâncias aos níveis de $1 \%, 5 \%$ e $10 \%$, respectivamente.

\subsubsection{Variáveis de controle}

Assim como nas regressões realizadas com a remuneração do conselho de administração, a variável que representa o tamanho da empresa neste modelo, logaritmo natural do ativo total - $\ln (\mathrm{CL})$, foi estatisticamente significativa em todas as regressões realizadas. Por exemplo, na coluna (1) da regressão realizada por efeitos aleatórios, um aumento de $10 \%$ no tamanho da companhia aumenta a remuneração fixa da diretoria em $3,2 \%$.

O número de membros da diretoria permanece estatisticamente relevante nos modelos utilizados e positivamente correlacionado com remuneração da diretoria, diferentemente do número de membros do conselho de administração, que não apresentou significância a 5\%. Ressalta-se que a análise sobre se o aumento de um membro na diretoria da companhia aumenta a remuneração média por diretor será feita apenas para a remuneração total desse colegiado (item 4.11), considerando as parcelas fixa, variável, entre outras existentes.

O segmento de listagem em que se encontra a companhia, impacta também a remuneração fixa da diretoria. Na coluna (2) da Tabela 9 da regressão por efeitos aleatórios, companhias listadas nos mais altos segmentos de listagem remuneram 23,7\% a mais seus diretores. 


\subsection{Remuneração variável da diretoria}

Importante esclarecer que em função de nem todas as companhias analisadas pagarem remunerações variáveis para os membros da diretoria, acrescentando aqui também eventuais companhias que deixam de atualizar corretamente os formulários de referência, o número de observações utilizadas nessas regressões, Tabela 10, é inferior àquele verificado no item que analisou a remuneração fixa da diretoria. Enquanto nas regressões analisadas nesse item as observações variam entre 793 e 967 registros, para remuneração fixa foram utilizados entre 1057 e 1350 registros.

Tabela 10 - Regressão: In natural de BD

Variável dependente: logaritmo natural da remuneração variável da diretoria

\begin{tabular}{|c|c|c|}
\hline Regressão por Painel: & \multicolumn{2}{|c|}{ efeitos fixos } \\
\hline Variáveis & (1) & (2) \\
\hline $\begin{array}{l}\mathbf{C Q} \\
\% \mathrm{ROA}\end{array}$ & $\begin{array}{c}0.006 \\
(1.471)\end{array}$ & $\begin{array}{c}0.005 \\
(0.575)\end{array}$ \\
\hline $\begin{array}{l}\text { CR } \\
\% \text { ROA defasado_1 ano }\end{array}$ & $\begin{array}{r}-0.000 * * * \\
(-18.954)\end{array}$ & $\begin{array}{c}0.009 \\
(1.187)\end{array}$ \\
\hline $\begin{array}{l}\text { CY1 } \\
\text { \% ROA defasado_2 anos }\end{array}$ & $\begin{array}{c}-0.000 * * * \\
(-2.781)\end{array}$ & $\begin{array}{c}-0.000 \\
(-1.608)\end{array}$ \\
\hline $\begin{array}{l}\ln (\mathbf{C L}) \\
\ln (\text { ativo total) }\end{array}$ & $\begin{array}{l}0.274 * * \\
(2.411)\end{array}$ & $\begin{array}{l}0.332 * \\
(1.823)\end{array}$ \\
\hline $\mathbf{M}$ - dummy - segmento de listagem & & $\begin{array}{c}-0.090 \\
(-0.468)\end{array}$ \\
\hline BX - \% votante do maior acionista & & $\begin{array}{c}0.005 \\
(1.321) \\
\end{array}$ \\
\hline $\begin{array}{l}\text { AA } \\
n^{\circ} \text { membros do CA }\end{array}$ & & $\begin{array}{c}0.026 \\
(0.621)\end{array}$ \\
\hline $\begin{array}{l}\text { AS } \\
n^{\mathbf{o}} \text { membros da Dir. }\end{array}$ & & $\begin{array}{c}0.006 \\
(0.203)\end{array}$ \\
\hline $\begin{array}{l}\text { CO } \\
\text { LPA (lucro por ação) }\end{array}$ & & $\begin{array}{r}0.001 * * * \\
(13.181)\end{array}$ \\
\hline $\begin{array}{l}\text { DA } \\
\text { retorno ação }\end{array}$ & & $\begin{array}{c}-0.001 \\
(-1.381)\end{array}$ \\
\hline $\begin{array}{l}\text { DTT } \\
\text { retorno ação_1 ano }\end{array}$ & & $\begin{array}{c}-0.000 \\
(-0.095)\end{array}$ \\
\hline $\mathbf{R}^{2}$ within & 0.07 & 0.11 \\
\hline $\mathbf{R}^{2}$ overall & 0.19 & 0.11 \\
\hline Obs. & 967 & 793 \\
\hline Teste de hausman (p-valor) & 0.0082 & 0.0912 \\
\hline
\end{tabular}

\begin{tabular}{|c|c|}
\hline \multicolumn{2}{|c|}{ efeitos aleatórios } \\
\hline (1) & (2) \\
\hline $\begin{array}{c}0.004 \\
(1.148)\end{array}$ & $\begin{array}{c}0.004 \\
(0.589)\end{array}$ \\
\hline $\begin{array}{c}-0.000 * * * \\
(-17.976)\end{array}$ & $\begin{array}{c}0.008 \\
(1.300)\end{array}$ \\
\hline $\begin{array}{c}-0.000 * * * \\
(-5.606)\end{array}$ & $\begin{array}{c}-0.000 * * \\
(-2.498)\end{array}$ \\
\hline $\begin{array}{c}0.365 * * * \\
(6.630)\end{array}$ & $\begin{array}{c}0.296 * * * \\
(4.109)\end{array}$ \\
\hline & $\begin{array}{c}0.553 * * * \\
(2.913)\end{array}$ \\
\hline & $\begin{array}{c}-0.004 \\
(-1.429)\end{array}$ \\
\hline & $\begin{array}{c}0.021 \\
(0.725)\end{array}$ \\
\hline & $\begin{array}{c}0.033 * * * \\
(2.649)\end{array}$ \\
\hline & $\begin{array}{c}0.001 * * * \\
(22.070)\end{array}$ \\
\hline & $\begin{array}{c}-0.001 \\
(-0.837)\end{array}$ \\
\hline & $\begin{array}{c}0.000 \\
(0.363) \\
\end{array}$ \\
\hline 0.07 & 0.09 \\
\hline 0.19 & 0.26 \\
\hline 967 & 793 \\
\hline
\end{tabular}

A variável dependente é representada pela remuneração variável (bônus, participação em reuniões, participação de resultados e outras remunerações variáveis) paga a todos os membros da diretoria. As variáveis $C Q, C R$ e CY1 medem o desempenho operacional, com as duas últimas sendo variáveis com 1 e 2 anos de defasagem, respectivamente. Tamanho da firma está 
representa pela variável ln (CL). A variável dummy M indica se determinada companhia está (1) ou não está (0) nos segmentes de listagem Novo Mercado e Nível 2. A variável BX representa o percentual do capital votante do acionista com mais ações ON no período. As variáveis AA e AS representam, respectivamente, o número de membros do Conselho de Administração e da Diretoria das sociedades. A variável CO representa o lucro por ação. As variáveis DA e DTT representam o retorno da ação mais negociada da companhia, sendo a DTT com 1 ano de defasagem. A regressão contém variáveis dummies de ano (2011 a 2014). A estatística t está indicada em parênteses. ***, **, * indicam as significâncias aos níveis de $1 \%, 5 \%$ e $10 \%$, respectivamente.

\subsubsection{Variáveis de desempenho}

As variáveis de desempenho contemporâneas não apresentaram significância estatística nas regressões realizadas para efeitos fixos. Já as defasadas, ROA_1 e ROA_2, apresentaram significância nas regressões listadas nas colunas (1) e (2). Os coeficientes dessas variáveis indicam, assim como para remuneração fixa da diretoria, que há correlação negativa entre desempenho operacional da companhia e remuneração variável da diretoria. Entretanto, o impacto do desempenho da remuneração é muito baixo; mudanças de $10 \%$ nas variáveis de desempenho afetam em menos de $0,5 \%$ a remuneração variável da diretoria.

\subsubsection{Variáveis de controle}

Os sinais das correlações verificadas nessas regressões são praticamente os mesmos daqueles observados no item da remuneração fixa da diretoria. Entretanto, os impactos observados para algumas variáveis são mais altos nas regressões desse item, causando um efeito maior na remuneração variável dos diretores. Em relação à variável segmento de listagem, temos que companhias listadas nos mais altos níveis de governança remuneram em $55 \%$ a mais a diretoria, em comparação com companhias não listadas nesses segmentos, conforme observado na coluna (2) da Tabela 10, por efeitos aleatórios.

A variável de estrutura de propriedade não se mostrou significativa estatisticamente em nenhuma dessas regressões analisadas. As variáveis de retorno das ações dessas companhias também não foram significativas. 


\subsection{Remuneração em ações da diretoria}

Nas regressões utilizando como variável dependente a remuneração em ações, Tabela 11, ocorre a mesma situação mencionada no item anterior, vez que nem todas as companhias analisadas pagaram remuneração em ações para os membros da diretoria. O número de observações chega a ser em algumas regressões apenas $30 \%$ do total verificado ao analisar a remuneração fixa da diretoria.

Tabela 11 - Regressão: In natural de BH

Variável dependente: logaritmo natural da remuneração total em ações da diretoria

\begin{tabular}{|c|c|c|}
\hline \multirow[t]{2}{*}{ Regressão por Painel: } & \multicolumn{2}{|c|}{ efeitos fixos } \\
\hline & (1) & (2) \\
\hline $\begin{array}{l}\text { CQ } \\
\% \text { ROA }\end{array}$ & $\begin{array}{l}0.004^{* *} \\
(2.412)\end{array}$ & $\begin{array}{l}0.008 \\
(1.056)\end{array}$ \\
\hline $\begin{array}{l}\text { CR } \\
\text { \% ROA defasado_1 ano }\end{array}$ & $\begin{array}{l}0.037^{* *} \\
(2.244)\end{array}$ & $\begin{array}{l}0.036^{*} \\
(1.839)\end{array}$ \\
\hline $\begin{array}{l}\text { CY1 } \\
\text { \% ROA defasado_2 anos }\end{array}$ & $\begin{array}{c}-0.000 * * * \\
(-14.296)\end{array}$ & $\begin{array}{l}-0.002 \\
(-0.227)\end{array}$ \\
\hline $\begin{array}{l}\ln (\mathbf{C L}) \\
\ln (\text { ativo total })\end{array}$ & $\begin{array}{c}0.389 \\
(1.207)\end{array}$ & $\begin{array}{c}0.597 \\
(1.504)\end{array}$ \\
\hline M - dummy - segmento de listagem & & $\begin{array}{c}1.010^{* * * *} \\
(5.732)\end{array}$ \\
\hline BX - \% votante do maior acionista & & $\begin{array}{c}0.000 \\
(0.051)\end{array}$ \\
\hline $\begin{array}{l}\mathbf{A A} \\
n^{\circ} \text { membros do CA }\end{array}$ & & $\begin{array}{l}0.156^{* * * *} \\
(2.715)\end{array}$ \\
\hline $\begin{array}{l}\text { AS } \\
n^{\circ} \text { membros da Dir. }\end{array}$ & & $\begin{array}{l}0.061^{*} \\
(1.930)\end{array}$ \\
\hline $\begin{array}{l}\text { CO } \\
\text { LPA (lucro por ação) }\end{array}$ & & $\begin{array}{c}0.001 \\
(0.100)\end{array}$ \\
\hline $\begin{array}{l}\text { DA } \\
\text { retorno ação }\end{array}$ & & $\begin{array}{l}-0.003^{*} \\
(-1.690)\end{array}$ \\
\hline $\begin{array}{l}\text { DTT } \\
\text { retorno ação_1 ano }\end{array}$ & & $\begin{array}{l}-0.000 \\
(-0.160) \\
\end{array}$ \\
\hline $\mathbf{R}^{2}$ within & 0.07 & 0.11 \\
\hline $\mathbf{R}^{2}$ overall & 0.18 & 0.28 \\
\hline Obs. & 445 & 380 \\
\hline Teste de hausman (p-valor) & 0.0084 & erro \\
\hline
\end{tabular}

\begin{tabular}{|c|c|}
\hline (1) & (2) \\
\hline $\begin{array}{c}0.002 \\
(1.614) \\
\end{array}$ & $\begin{array}{c}0.003 \\
(0.596) \\
\end{array}$ \\
\hline $\begin{array}{c}0.031 * * * \\
(2.621)\end{array}$ & $\begin{array}{c}0.035 * * \\
(2.393)\end{array}$ \\
\hline $\begin{array}{c}-0.000 * * * \\
(-21.150)\end{array}$ & $\begin{array}{c}-0.008 \\
(-1.044)\end{array}$ \\
\hline \multirow[t]{8}{*}{$\begin{array}{c}0.492 * * * \\
(6.176) \\
\end{array}$} & $\begin{array}{c}0.411 * * * \\
(3.918)\end{array}$ \\
\hline & $\begin{array}{c}0.297 \\
(0.820)\end{array}$ \\
\hline & $\begin{array}{c}-0.007 \\
(-1.521) \\
\end{array}$ \\
\hline & $\begin{array}{c}0.119 * * * \\
(3.432)\end{array}$ \\
\hline & $\begin{array}{c}0.048 * * \\
(2.367)\end{array}$ \\
\hline & $\begin{array}{l}0.001 * \\
(1.684)\end{array}$ \\
\hline & $\begin{array}{l}-0.003 * \\
(-1.692)\end{array}$ \\
\hline & $\begin{array}{c}-0.000 \\
(-0.217)\end{array}$ \\
\hline 0.07 & 0.09 \\
\hline 0.20 & 0.31 \\
\hline 445 & 380 \\
\hline
\end{tabular}

A variável dependente é representada pela remuneração baseada em ações paga a todos os membros da diretoria. As variáveis CQ, CR e CY1 medem o desempenho operacional, com as duas últimas sendo variáveis com 1 e 2 anos de defasagem, respectivamente. Tamanho da firma está representa pela variável ln (CL). A variável dummy M indica se determinada companhia está (1) ou não está (0) nos segmentes de listagem Novo Mercado e Nível 2. A variável BX representa o percentual do capital votante do acionista com mais ações ON no período. As variáveis AA e AS representam, respectivamente, o número de membros do Conselho de Administração e da Diretoria das sociedades. A variável CO representa o lucro por ação. As variáveis DA e DTT representam o retorno da ação mais negociada da companhia, sendo a DTT com 1 ano de defasagem. A regressão contém variáveis dummies de ano (2011 a 2014). A estatística t está indicada em parênteses. $* * *, * *, *$ indicam as significâncias aos níveis de $1 \%, 5 \%$ e $10 \%$, respectivamente. 


\subsubsection{Variáveis de desempenho}

A variável de desempenho com 1 ano de defasagem apresentou-se estatisticamente significativa nas duas regressões realizas pelo método de efeitos fixos. A com 2 anos de defasagem, relevante na coluna (1), assim como a variável contemporânea.

Os coeficientes mais significativos são os da variável com 1 ano de defasagem. $\mathrm{Na}$ coluna (1), por exemplo, aumento de $10 \%$ no desempenho aumenta em $37 \%$ a remuneração em ações da diretoria, um aumento extremamente significativo. Nessa mesma regressão da coluna (1), a variável contemporânea de desempenho também está positivamente correlacionada com remuneração em ações da diretoria, um aumento em $10 \%$ no desempenho aumenta em 4\% a remuneração em ações da diretoria. A variável com 2 anos de defasagem apresenta correlação negativa, mas a magnitude do coeficiente é irrelevante.

\subsubsection{Variáveis de controle}

Algumas variáveis de controle utilizadas nas regressões da Tabela 11 apresentam forte relação com a remuneração em ações da diretoria, pelo método de efeitos aleatórios. Cabe ressaltar que o $\mathrm{n}^{\mathrm{o}}$ de membros do conselho de administração da companhia impacta mais na remuneração em ações da diretoria que o próprio $\mathrm{n}^{\circ}$ de membros da diretoria. Para cada membro adicional no conselho de administração, a remuneração em ações da diretoria aumenta em 11,9\%, conforme coluna (2) da Tabela 11. Já para cada diretor adicional, temos um aumento na remuneração em ações de 4,8\%, que se apresenta também significativo.

Entretanto, a variável ln (CL) não é significativa nas regressões realizadas pelo método de efeitos fixos, apenas usando efeitos aleatórios, diferentemente daquilo observado nas regressões anteriores. 


\subsection{Remuneração total da diretoria}

Na remuneração total da diretoria, Tabela 12, estão incluídas as remunerações fixa, variável, por ação, bônus e qualquer outro benefício financeiro recebido pelos membros do conselho de administração ao longo dos exercícios financeiros analisados.

\section{Tabela 12 - Regressão: In natural de BJ}

Variável dependente: logaritmo natural da remuneração total da diretoria

\begin{tabular}{|c|c|c|}
\hline \multirow[t]{2}{*}{ Regressão por Painel: } & \multicolumn{2}{|c|}{ efeitos fixos } \\
\hline & (1) & (2) \\
\hline $\begin{array}{l}\text { CQ } \\
\% \text { ROA }\end{array}$ & $\begin{array}{l}0.002 * * \\
(2.128)\end{array}$ & $\begin{array}{c}-0.000 \\
(-0.072)\end{array}$ \\
\hline $\begin{array}{l}\text { CR } \\
\% \text { ROA defasado_1 ano }\end{array}$ & $\begin{array}{l}-0.000 * * * \\
(-9.794)\end{array}$ & $\begin{array}{c}0.004 \\
(1.553)\end{array}$ \\
\hline $\begin{array}{l}\text { CY1 } \\
\text { \% ROA defasado_2 anos }\end{array}$ & $\begin{array}{l}-0.000 * * * \\
(-30.700)\end{array}$ & $\begin{array}{c}-0.000 * * * \\
(-6.894)\end{array}$ \\
\hline $\begin{array}{l}\ln (\mathbf{C L}) \\
\ln (\text { ativo total })\end{array}$ & $\begin{array}{l}0.188 * \\
(1.907) \\
\end{array}$ & $\begin{array}{c}0.316 * * * \\
(4.272)\end{array}$ \\
\hline M - dummy - segmento de listagem & & $\begin{array}{c}0.067 \\
(0.353)\end{array}$ \\
\hline BX - \% votante do maior acionista & & $\begin{array}{c}0.000 \\
(0.274)\end{array}$ \\
\hline $\begin{array}{l}\mathbf{A A} \\
\mathrm{n}^{\circ} \text { membros do CA }\end{array}$ & & $\begin{array}{c}0.006 \\
(0.440)\end{array}$ \\
\hline $\begin{array}{l}\text { AS } \\
n^{\circ} \text { membros da Dir. }\end{array}$ & & $\begin{array}{c}0.049 * * * \\
(2.692)\end{array}$ \\
\hline $\begin{array}{l}\text { CO } \\
\text { LPA (lucro por ação) }\end{array}$ & & $\begin{array}{c}0.000 * * * \\
(7.145)\end{array}$ \\
\hline $\begin{array}{l}\text { DA } \\
\text { retorno ação }\end{array}$ & & $\begin{array}{c}0.000 \\
(0.904)\end{array}$ \\
\hline $\begin{array}{l}\text { DTT } \\
\text { retorno ação_1 ano }\end{array}$ & & $\begin{array}{l}0.001 * * \\
(2.585)\end{array}$ \\
\hline $\mathbf{R}^{2}$ within & 0.14 & 0.19 \\
\hline $\mathbf{R}^{2}$ overall & 0.43 & 0.47 \\
\hline Obs. & 1359 & 1061 \\
\hline Teste de hausman (p-valor) & 0.0000 & 0.2742 \\
\hline
\end{tabular}

\begin{tabular}{|c|c|}
\hline (1) & (2) \\
\hline $\begin{array}{l}0.001 * \\
(1.819)\end{array}$ & $\begin{array}{c}-0.000 \\
(-0.174)\end{array}$ \\
\hline $\begin{array}{l}-0.000 * * * \\
(-10.178)\end{array}$ & $\begin{array}{c}0.004 * * \\
(2.168)\end{array}$ \\
\hline $\begin{array}{c}-0.000 * * * \\
(-35.170)\end{array}$ & $\begin{array}{c}-0.000 * * * \\
(-7.167)\end{array}$ \\
\hline \multirow[t]{8}{*}{$\begin{array}{c}0.409 * * * \\
(8.132)\end{array}$} & $\begin{array}{c}0.329 * * * \\
(8.390)\end{array}$ \\
\hline & $\begin{array}{c}0.533 * * * \\
(4.255)\end{array}$ \\
\hline & $\begin{array}{c}-0.003 * * \\
(-2.018)\end{array}$ \\
\hline & $\begin{array}{c}0.011 \\
(0.931)\end{array}$ \\
\hline & $\begin{array}{c}0.047 * * * \\
(5.252)\end{array}$ \\
\hline & $\begin{array}{c}0.000 * * * \\
(14.786)\end{array}$ \\
\hline & $\begin{array}{c}0.001 \\
(1.234)\end{array}$ \\
\hline & $\begin{array}{c}0.001 * * * \\
(3.043)\end{array}$ \\
\hline 0.13 & 0.18 \\
\hline 0.45 & 0.53 \\
\hline 1359 & 1061 \\
\hline
\end{tabular}

A variável dependente é representada pela remuneração total (fixa + variável + ações + outras) paga a todos os membros da diretoria. As variáveis CQ, CR e CY1 medem o desempenho operacional, com as duas últimas sendo variáveis com 1 e 2 anos de defasagem, respectivamente. Tamanho da firma está representa pela variável ln (CL). A variável dummy M indica se determinada companhia está (1) ou não está (0) nos segmentes de listagem Novo Mercado e Nível 2. A variável BX representa o percentual do capital votante do acionista com mais ações ON no período. As variáveis AA e AS representam, respectivamente, o número de membros do Conselho de Administração e da Diretoria das sociedades. A variável CO representa o lucro por ação. As variáveis DA e DTT representam o retorno da ação mais negociada da companhia, sendo a DTT com 1 ano de defasagem. A regressão contém variáveis dummies de ano (2011 a 2014). A estatística t está indicada em parênteses. $* * * * *, *$ indicam as significâncias aos níveis de $1 \%, 5 \%$ e $10 \%$, respectivamente. 


\subsubsection{Variáveis de desempenho}

As variáveis de desempenho: contemporâneo, com 1 e 2 anos de defasagem, mostraram-se estatisticamente significativas na regressão ao se utilizar o método de efeitos fixos, coluna (1). A variável contemporânea é a que apresenta o maior coeficiente, em que um aumento de $10 \%$ no desempenho da companhia aumenta em $2 \%$ a remuneração total da diretoria, conforme coluna (1). Embora as variáveis defasadas sejam estatisticamente significativas, seus coeficientes não geram impactos relevantes na remuneração da diretoria e eles são negativamente correlacionados com a remuneração.

\subsubsection{Variáveis de controle}

Analisando a coluna (2) da Tabela 12 para efeitos aleatórios, verifica-se que a maioria das variáveis de controle são estatisticamente significantes e impactam de forma relevante a remuneração total da diretoria da companhia. O tamanho da empresa está positivamente correlacionado com remuneração, ou seja, pela coluna (2), aumento de $10 \%$ no tamanho da empresa, aumenta em $3,2 \%$ a remuneração da diretoria.

Companhias que estão listadas nos altos segmentos de governança da BM\&FBOVESPA remuneram em 53\% a mais sua diretoria que as companhias que não estão listadas nesses segmentos. Em relação à estrutura de propriedade, companhias com maior dispersão de suas ações pagam mais aos seus diretores que companhias com controle e concentração de ações em poucos acionistas. $\mathrm{O} \mathrm{n}^{\mathbf{o}}$ de membros da diretoria continua impactando de forma relevante a remuneração dos diretores. Já o $\mathrm{n}^{\circ}$ de membros do conselho de administração não apresentou significância estatística.

\subsection{Remuneração média por diretor}

Alguns destaques são importantes fazer quando utilizamos remuneração média em vez de remuneração total, conforme item anterior, para a variável dependente. Em relação às 
variáveis de controle, verifica-se que a variável que representa o $\mathrm{n}^{\mathrm{o}}$ de membros da diretoria apresenta relação negativa com a remuneração média por diretor. Com isso, embora em boa parte das regressões anteriores tenha sido encontrada relação positiva e significativa entre tamanho da diretoria e remuneração, pela regressão da Tabela 13, verifica-se que o aumento de membros na diretoria não aumenta a remuneração média desse colegiado, pelo contrário, há evidência que quanto mais diretores, menor será a remuneração média paga. Assim, tem-se que o montante total pago à diretoria em forma de remuneração aumenta com a adição de novos membros, porém, a remuneração média é reduzida.

Já a variável que representa o tamanho do conselho, apresenta a mesma interpretação da regressão anteriormente realizada - com a remuneração total do conselho. Com isso, não há evidências de que o $\mathrm{n}^{\mathrm{o}}$ de conselheiros nas companhias afete a remuneração total ou média paga aos membros da diretoria.

\section{Tabela 13 - Regressão: In natural de BT1}

Variável dependente: logaritmo natural da remuneração média por diretor

\begin{tabular}{|c|c|c|}
\hline \multirow[t]{2}{*}{ Regressão por Painel: } & \multicolumn{2}{|c|}{ efeitos fixos } \\
\hline & (1) & (2) \\
\hline $\begin{array}{l}\text { CQ } \\
\% \text { ROA }\end{array}$ & $\begin{array}{c}0.002 * * * \\
(3.006)\end{array}$ & $\begin{array}{c}0.000 \\
(0.134)\end{array}$ \\
\hline $\begin{array}{l}\text { CR } \\
\% \text { ROA defasado_1 ano }\end{array}$ & $\begin{array}{l}-0.000 * * * \\
(-10.299)\end{array}$ & $\begin{array}{c}0.004 \\
(1.593)\end{array}$ \\
\hline $\begin{array}{l}\text { CY1 } \\
\text { \% ROA defasado } 2 \text { anos }\end{array}$ & $\begin{array}{c}-0.000 * * * \\
(-28.374)\end{array}$ & $\begin{array}{c}-0.000 * * * \\
(-7.395)\end{array}$ \\
\hline $\begin{array}{l}\ln (\mathbf{C L}) \\
\ln (\text { ativo total) }\end{array}$ & $\begin{array}{c}0.088 \\
(1.005) \\
\end{array}$ & $\begin{array}{c}0.228 * * * \\
(3.162)\end{array}$ \\
\hline $\mathbf{M}$ - dummy - segmento de listagem & & $\begin{array}{c}0.088 \\
(0.378)\end{array}$ \\
\hline BX - \% votante do maior acionista & & $\begin{array}{c}-0.000 \\
(-0.124)\end{array}$ \\
\hline $\begin{array}{l}\mathbf{A A} \\
n^{\circ} \text { membros do CA }\end{array}$ & & $\begin{array}{c}-0.016 \\
(-0.953)\end{array}$ \\
\hline $\begin{array}{l}\text { AS } \\
n^{\mathbf{o}} \text { membros da Dir. }\end{array}$ & & $\begin{array}{c}-0.056 * * * \\
(-4.925)\end{array}$ \\
\hline $\begin{array}{l}\text { CO } \\
\text { LPA (lucro por ação) }\end{array}$ & & $\begin{array}{c}0.000 * * * \\
(7.960)\end{array}$ \\
\hline $\begin{array}{l}\text { DA } \\
\text { retorno ação }\end{array}$ & & $\begin{array}{c}0.000 \\
(0.601)\end{array}$ \\
\hline $\begin{array}{l}\text { DTT } \\
\text { retorno ação_1 ano }\end{array}$ & & $\begin{array}{l}0.001 * * \\
(2.220)\end{array}$ \\
\hline $\mathbf{R}^{2}$ within & 0.13 & 0.16 \\
\hline $\mathbf{R}^{2}$ overall & 0.26 & 0.16 \\
\hline Obs. & 1359 & 1061 \\
\hline Teste de hausman (p-valor) & 0.0084 & 0.0003 \\
\hline
\end{tabular}

\begin{tabular}{|c|c|}
\hline (1) & (2) \\
\hline $\begin{array}{c}0.002 * * * \\
(3.188) \\
\end{array}$ & $\begin{array}{c}-0.000 \\
(-0.122) \\
\end{array}$ \\
\hline $\begin{array}{c}-0.000 * * * \\
(-9.288)\end{array}$ & $\begin{array}{c}0.004 * * \\
(2.078)\end{array}$ \\
\hline $\begin{array}{c}-0.000 * * * \\
(-33.236)\end{array}$ & $\begin{array}{c}-0.000 * * * \\
(-6.137)\end{array}$ \\
\hline \multirow[t]{8}{*}{$\begin{array}{c}0.264 * * * \\
(6.125)\end{array}$} & $\begin{array}{c}0.282 * * * \\
(7.345)\end{array}$ \\
\hline & $\begin{array}{c}0.464 * * * * \\
(3.832)\end{array}$ \\
\hline & $\begin{array}{c}-0.003 * * \\
(-2.028)\end{array}$ \\
\hline & $\begin{array}{c}-0.014 \\
(-1.087)\end{array}$ \\
\hline & $\begin{array}{l}-0.023 * \\
(-1.801)\end{array}$ \\
\hline & $\begin{array}{c}0.000 * * * \\
(4.869)\end{array}$ \\
\hline & $\begin{array}{c}0.000 \\
(0.880)\end{array}$ \\
\hline & $\begin{array}{c}0.001 * * \\
(2.559)\end{array}$ \\
\hline 0.12 & 0.14 \\
\hline 0.30 & 0.33 \\
\hline 1359 & 1061 \\
\hline
\end{tabular}


A variável dependente é representada pela remuneração média paga a todos os membros da diretoria. As variáveis $C Q$, $C R$ e CY1 medem o desempenho operacional, com as duas últimas sendo variáveis com 1 e 2 anos de defasagem, respectivamente. Tamanho da firma está representa pela variável ln (CL). A variável dummy M indica se determinada companhia está (1) ou não está (0) nos segmentes de listagem Novo Mercado e Nível 2. A variável BX representa o percentual do capital votante do acionista com mais ações ON no período. As variáveis AA e AS representam, respectivamente, o número de membros do Conselho de Administração e da Diretoria das sociedades. A variável CO representa o lucro por ação. As variáveis DA e DTT representam o retorno da ação mais negociada da companhia, sendo a DTT com 1 ano de defasagem. A regressão contém variáveis dummies de ano (2011 a 2014). A estatística t está indicada em parênteses. ***, **,* indicam as significâncias aos níveis de $1 \%, 5 \%$ e $10 \%$, respectivamente.

\subsection{Maior e menor remuneração da diretoria}

\subsubsection{Variáveis de desempenho}

Apenas as variáveis de desempenho defasadas em 2 anos são estatisticamente significativas nas regressões utilizando como variável dependente a maior ou menor remuneração da diretoria, pelo método de efeitos fixos, conforme Tabela 14 e Tabela 15. A correlação existente é negativa, entretanto, a magnitude do efeito do desempenho na remuneração é muito baixa.

Tabela 14 - Regressão: In natural de BM

Variável dependente: logaritmo natural da maior remuneração total da diretoria

\begin{tabular}{|l|c|c|}
\multicolumn{1}{|c}{ Regressão por Painel: } & $(\mathbf{1})$ & $(\mathbf{2})$ \\
\hline CQ & & \\
\% ROA & 0.001 & 0.000 \\
\hline CR & $(0.800)$ & $(0.198)$ \\
\% ROA defasado_1 ano & 0.002 & 0.004 \\
CY1 & $(1.316)$ & $(1.452)$ \\
\% ROA defasado_2 anos & $-0.000^{* * *}$ & 0.001 \\
\hline In (CL) & $(-23.992)$ & $(0.968)$ \\
ln (ativo total) & 0.111 & $0.353 * * *$ \\
\hline M - dummy - segmento de listagem & $(1.059)$ & $(2.833)$ \\
\hline BX - \% votante do maior acionista & & -0.078 \\
& & $(-0.479)$ \\
\hline AA & & -0.001 \\
$n^{\circ}$ membros do CA & & $(-0.404)$ \\
\hline AS & & 0.005 \\
$n^{\circ}$ membros da Dir. & & $(0.303)$ \\
\hline CO & & -0.013 \\
LPA (lucro por ação) & & $(-0.791)$ \\
\hline DA & & $(1.552)$ \\
\hline
\end{tabular}

efeitos aleatórios

\begin{tabular}{|c|c|}
\hline $\mathbf{( 1 )}$ & $\mathbf{( 2 )}$ \\
\hline 0.001 & 0.001 \\
$(0.631)$ & $(0.536)$ \\
\hline 0.002 & $0.004 *$ \\
$(1.268)$ & $(1.704)$ \\
\hline$-0.000 * * *$ & $0.002 *$ \\
$(-32.402)$ & $(1.652)$ \\
\hline $0.314 * * *$ & $0.290 * * *$ \\
$(6.224)$ & $(6.122)$ \\
\hline & $0.752 * * *$ \\
& $(4.671)$ \\
\hline & $-0.007 * * *$ \\
& $(-2.594)$ \\
\hline & -0.000 \\
& $(-0.030)$ \\
\hline & -0.016 \\
& $(-1.118)$ \\
\hline & 0.000 \\
& $(1.202)$ \\
\hline & -0.000 \\
\hline
\end{tabular}




\begin{tabular}{|l|c|c|c|c|}
\hline retorno ação & & $(-0.287)$ \\
\hline $\begin{array}{l}\text { DTT } \\
\text { retorno ação_1 ano }\end{array}$ & & $\begin{array}{c}0.002 * * * \\
(4.446)\end{array}$ \\
\hline & & & & $(-0.360)$ \\
\hline $\mathbf{R}^{2}$ within & 0.10 & 0.13 \\
\cline { 1 - 3 } $\mathbf{R}^{2}$ overall & 0.24 & 0.26 \\
\hline Obs. & 1063 & 835 \\
\hline Teste de hausman (p-valor) & 0.1418 & 0.9659 \\
\cline { 1 - 2 }
\end{tabular}

A variável dependente é representada pela maior remuneração paga entre os membros da diretoria. As variáveis CQ, CR e CY1 medem o desempenho operacional, com as duas últimas sendo variáveis com 1 e 2 anos de defasagem, respectivamente. Tamanho da firma está representa pela variável ln (CL). A variável dummy M indica se determinada companhia está (1) ou não está (0) nos segmentes de listagem Novo Mercado e Nível 2. A variável BX representa o percentual do capital votante do acionista com mais ações ON no período. As variáveis AA e AS representam, respectivamente, o número de membros do Conselho de Administração e da Diretoria das sociedades. A variável CO representa o lucro por ação. As variáveis DA e DTT representam o retorno da ação mais negociada da companhia, sendo a DTT com 1 ano de defasagem. A regressão contém variáveis dummies de ano (2011 a 2014). A estatística t está indicada em parênteses. ***, **, * indicam as significâncias aos níveis de $1 \%, 5 \%$ e $10 \%$, respectivamente.

\section{Tabela 15 - Regressão: In natural de BN}

Variável dependente: logaritmo natural da menor remuneração total da diretoria

Regressão por Painel:

\begin{tabular}{|c|c|c|}
\hline & \multirow{2}{*}{\multicolumn{2}{|c|}{ (1) }} \\
\hline & & (2) \\
\hline $\begin{array}{l}\text { CQ } \\
\% \mathrm{ROA}\end{array}$ & $\begin{array}{c}0.001 \\
(0.524)\end{array}$ & $\begin{array}{c}-0.000 \\
(-0.105)\end{array}$ \\
\hline $\begin{array}{l}\text { CR } \\
\text { \% ROA defasado_1 ano }\end{array}$ & $\begin{array}{c}0.001 \\
(0.777)\end{array}$ & $\begin{array}{c}0.001 \\
(0.486)\end{array}$ \\
\hline $\begin{array}{l}\text { CY1 } \\
\text { \% ROA defasado_2 anos }\end{array}$ & $\begin{array}{l}-0.000 * * * \\
(-15.449) \\
\end{array}$ & $\begin{array}{c}0.004 \\
(1.634) \\
\end{array}$ \\
\hline $\begin{array}{l}\ln (\mathbf{C L}) \\
\ln (\text { ativo total) }\end{array}$ & $\begin{array}{c}0.129 \\
(0.626)\end{array}$ & $\begin{array}{c}0.054 \\
(0.216)\end{array}$ \\
\hline M - dummy - segmento de listagem & & $\begin{array}{c}0.038 \\
(0.229)\end{array}$ \\
\hline BX - \% votante do maior acionista & & $\begin{array}{c}-0.002 \\
(-0.376)\end{array}$ \\
\hline $\begin{array}{l}\text { AA } \\
n^{\circ} \text { membros do CA }\end{array}$ & & $\begin{array}{c}0.031 \\
(0.916)\end{array}$ \\
\hline $\begin{array}{l}\text { AS } \\
n^{\mathbf{o}} \text { membros da Dir. }\end{array}$ & & $\begin{array}{c}-0.023 \\
(-0.566)\end{array}$ \\
\hline $\begin{array}{l}\text { CO } \\
\text { LPA (lucro por ação) }\end{array}$ & & $\begin{array}{c}0.000 * * * \\
(10.280) \\
\end{array}$ \\
\hline $\begin{array}{l}\text { DA } \\
\text { retorno ação }\end{array}$ & & $\begin{array}{c}-0.001 \\
(-0.912)\end{array}$ \\
\hline $\begin{array}{l}\text { DTT } \\
\text { retorno ação_1 ano }\end{array}$ & & $\begin{array}{c}0.001 \\
(1.231) \\
\end{array}$ \\
\hline $\mathbf{R}^{2}$ within & 0.04 & 0.04 \\
\hline $\mathbf{R}^{2}$ overall & 0.18 & 0.21 \\
\hline Obs. & 1057 & 832 \\
\hline Teste de hausman (p-valor) & 0.0200 & 0.1237 \\
\hline
\end{tabular}

efeitos aleatórios

\begin{tabular}{|c|c|}
\hline (1) & (2) \\
\hline $\begin{array}{c}0.002 \\
(0.903)\end{array}$ & $\begin{array}{c}-0.000 \\
(-0.101)\end{array}$ \\
\hline $\begin{array}{c}0.001 \\
(1.184)\end{array}$ & $\begin{array}{c}0.001 \\
(0.710)\end{array}$ \\
\hline $\begin{array}{c}-0.000 * * * \\
(-31.009)\end{array}$ & $\begin{array}{l}0.005^{* *} \\
(2.344)\end{array}$ \\
\hline \multirow[t]{8}{*}{$\begin{array}{c}0.303^{* * *} * \\
(6.077)\end{array}$} & $\begin{array}{c}0.240 * * * \\
(5.389)\end{array}$ \\
\hline & $\begin{array}{c}0.586^{* * *} \\
(3.842)\end{array}$ \\
\hline & $\begin{array}{c}-0.009 * * * \\
(-2.836)\end{array}$ \\
\hline & $\begin{array}{l}0.031^{*} \\
(1.958)\end{array}$ \\
\hline & $\begin{array}{l}-0.027 * \\
(-1.674)\end{array}$ \\
\hline & $\begin{array}{c}0.000 * * * \\
(6.391)\end{array}$ \\
\hline & $\begin{array}{c}-0.001 \\
(-0.604)\end{array}$ \\
\hline & $\begin{array}{c}0.001 \\
(1.627)\end{array}$ \\
\hline 0.04 & 0.04 \\
\hline 0.18 & 0.32 \\
\hline 1057 & 832 \\
\hline
\end{tabular}

A variável dependente é representada pela menor remuneração paga entre os membros da diretoria. As variáveis CQ, CR e CY1 medem o desempenho operacional, com as duas últimas sendo variáveis com 1 e 2 anos de defasagem, respectivamente. Tamanho da firma está representa pela variável ln (CL). A variável dummy M indica se determinada companhia está (1) ou não está (0) nos segmentes de listagem Novo Mercado e Nível 2. A variável BX representa o percentual do capital votante do acionista com mais ações ON no período. As variáveis AA e AS representam, respectivamente, o número de membros do 
Conselho de Administração e da Diretoria das sociedades. A variável CO representa o lucro por ação. As variáveis DA e DTT representam o retorno da ação mais negociada da companhia, sendo a DTT com 1 ano de defasagem. A regressão contém variáveis dummies de ano (2011 a 2014). A estatística t está indicada em parênteses. ***, **, * indicam as significâncias aos níveis de $1 \%, 5 \%$ e $10 \%$, respectivamente.

\subsubsection{Variáveis de controle}

Tanto nas regressões com a maior quanto com a menor remuneração da diretoria o segmento de listagem em que a companhia está listada tem um relevante impacto na maior e menor remuneração paga à diretoria. Conforme coluna (2) da Tabela 14 da regressão realizada por efeitos aleatórios, companhias listadas nos segmentos da BM\&FBOVESPA de alta governança pagam remuneração $75 \%$ mais alta para os seus diretores, quando comparadas com as companhias que não estão listadas nesses segmentos.

Em ambas as situações, maior concentração acionária implica em menores remunerações a esses diretores. Na coluna (2) da Tabela 15, temos que um aumento em 10\% no percentual votante do maior acionista, reduz a menor remuneração recebida na diretoria em $9 \%$. 


\section{Conclusões}

Utilizando um conjunto de dados inédito no Brasil, o presente estudo analisa, por meio de regressões com dados em painel, se há relação significativa entre remuneração de administradores e desempenho operacional das companhias com ações negociadas na bolsa de valores brasileira. Também foram analisados os impactos de diversas variáveis de controle, ligadas à estrutura de propriedade e à governança, na remuneração dos membros do conselho de administração e da diretoria.

No Brasil, há poucas análises comparando o efeito do desempenho operacional registrado pelas companhias na remuneração dos seus diretores e conselheiros de administração, tendo em vista a dificuldade de se obter dados confiáveis sobre a remuneração desses executivos até o ano de 2009 (Chien, 2012; Araújo, 2016; Vasconcelos e Monte, 2013; Camargos e Helal, 2005).

A partir de 2009, o órgão regulador do mercado de capitais no Brasil passou a exigir de todas as companhias abertas a divulgação de um conjunto de informações com o intuito de aumentar a transparência de atos por elas praticados.

Com isso, este estudo se propôs a analisar de forma individualizada eventuais impactos do desempenho operacional das companhias nos diferentes elementos da remuneração paga aos administradores, quais sejam, remuneração fixa, variável e por ações.

Também foram analisadas eventuais relações com a remuneração total paga a cada órgão e em relação aos menores e maiores valores totais pagos para os membros da diretoria e do conselho de administração. A pesquisa foi realizada coletando informações de 331 companhias abertas, que possuíam ações listadas na BM\&FBOVESPA durante o período de 2010 a 2014.

Os resultados encontrados neste trabalho, em relação ao conselho de administração, apontam para diferentes interpretações a depender de qual elemento da remuneração do conselheiro estava sendo utilizado na regressão. A remuneração fixa do conselho apresentou relação negativa com o desempenho da companhia, mas apenas em relação aos dados contemporâneos e o impacto verificado é muito baixo na remuneração do executivo.

As variáveis defasadas de 1 e 2 anos não foram significativamente relevantes. Há estudos na literatura com resultados similares a esses encontrados (Barontini e Bozzi, 2011; Bart, 2009; Mcknight, 1996 e Duffhues e Kabir, 2007). 
Já a remuneração paga em ações ao conselho apresentou correlação positiva e relevante com o desempenho da companhia, em linha com algumas literaturas sobre o tema (Hubbard e Palia, 1975; Murphy, 1985; John et al. 1999; Shim, 2015; Elston e Goldberg, 2003; Shakerin, 2014; Kaplan, 1994). Mas a relevância estatística foi identificada apenas em uma regressão com dados contemporâneos. Vale destacar o reduzido número de observações obtidas nas regressões com remuneração em ações, tendo em vista que poucas companhias remuneram seu conselho com ações, sendo predominante o pagamento com parcela fixa.

Em geral, nas outras regressões realizadas utilizando os vários tipos de remuneração paga aos conselheiros coletadas neste trabalho, as variáveis de desempenho não foram estatisticamente significativas. Com relação às variáveis de controle utilizadas nas regressões, houve uma confirmação, em grande medida, dos resultados encontrados na literatura, como em John et al. (1999) e Pinto (2013).

A variável ativo total, utilizada como proxy do tamanho da companhia, foi estatisticamente significativa e positivamente correlacionada com os vários tipos de remuneração paga aos administradores. Como exemplo, a coluna (2) da Tabela 5, utilizando efeitos fixos, demonstra que um aumento de $10 \%$ no tamanho da companhia aumenta em $3,4 \%$ a remuneração fixa do conselho. Ou seja, companhias maiores tendem a pagar maiores salários aos seus conselheiros de administração, em linha com o encontrado em diversos estudos, entre eles, Duffhues e Kabir (2007); Kaplan (1994); Bart, 2009 e Pinto (2013).

O segmento de listagem em que a companhia negocia suas ações na BM\&FBOVESPA também mostrou ser relevante na remuneração paga aos conselheiros. Em algumas regressões, como as da Tabela 5, companhias listadas nos segmentos de maior governança corporativa da bolsa tendem a pagar, em média, 30\% a mais para seu conselho de administração em comparação com aquelas companhias que não estão listadas nesses segmentos.

Ainda em relação às regressões realizadas com as remunerações dos conselheiros, verificou-se que quanto maior o número de membros deste colegiado maior tende a ser a remuneração total paga. Entretanto, quando essa variável é analisada com a remuneração média por conselheiro os resultados são diferentes: o aumento do número de conselheiro não eleva a remuneração média desse colegiado, pelo contrário, há evidência que quanto maior o conselho, menor será a remuneração média paga.

Já em relação à variável que representa o tamanho da diretoria da companhia, há evidências, a $10 \%$ de significância, que quanto maior o número de diretores nas companhias 
maior será a remuneração total do conselho de administração e maior será a remuneração média por conselheiro.

As regressões com as remunerações dos diretores como variável dependente, assim como nos resultados encontrados nas regressões realizadas com as remunerações do conselho de administração, apresentaram interpretações diferentes a depender de qual elemento da remuneração da diretoria estava sendo utilizado para avaliar a relação com o desempenho da companhia.

Em diversas regressões, utilizando dados da remuneração fixa, variável, por ações ou total da diretoria foi possível verificar relação negativa entre remuneração da diretoria e desempenho da companhia. Entretanto, via de regra, os coeficientes encontrados foram baixos, com impacto não significativo do desempenho na remuneração da diretoria. Há estudos na literatura com resultados similares a esses encontrados (Barontini e Bozzi, 2011; Bart, 2009; Mcknight, 1996 e Duffhues e Kabir, 2007).

Mas em duas regressões, utilizando dados da remuneração em ações e remuneração total da diretoria, as relações encontradas foram positivas e significativas, mais do que compensando os baixos efeitos negativos mencionados no parágrafo anterior, em linha com alguns estudos sobre o tema (Hubbard e Palia, 1975; Murphy, 1985; John et al. 1999; Shim, 2015; Elston e Goldberg, 2003; Shakerin, 2014; Kaplan, 1994).

Como exemplo, na coluna (1) da Tabela 11 por efeitos fixos, um aumento de $10 \%$ no desempenho operacional da companhia aumenta em $37 \%$ a remuneração em ações da diretoria, um aumento extremamente significativo. Embora a relação da variável de desempenho com 2 anos de defasagem seja negativa nesse caso, o coeficiente apresentado é muito baixo, com impacto irrelevante na remuneração.

Com relação às variáveis de controle utilizadas nas regressões, assim como na análise usando a remuneração do conselho, houve também uma confirmação, em grande medida, dos resultados encontrados na literatura.

A variável ativo total, utilizada como proxy do tamanho da companhia, foi estatisticamente significativa e positivamente correlacionada com os vários tipos de remuneração pagas aos diretores. Demonstrando que companhias maiores tendem a pagar salários maiores, em linha com o encontrado em diversos estudos, entre eles, Duffhues e Kabir (2007); Kaplan (1994); Bart, 2009 e Pinto (2013).

Para a estrutura de propriedade da companhia, foi utilizada a variável que mede o percentual de ações votante do maior acionista. Os resultados encontrados estão, na maioria 
das regressões realizadas, de acordo com a literatura sobre o assunto mencionada neste trabalho, em que companhias com propriedade acionária dispersa tendem a pagar mais aos seus administradores do que as demais. Isso pode ocorrer em função dos acionistas dispersos terem maiores dificuldades para controlar a remuneração dos diretores (Pinto, 2013).

O tamanho do órgão diretoria, na maioria das regressões, apresentou relação positiva e significativa em relação à remuneração paga aos diretores das companhias. Entretanto, quando a variável que representa o tamanho da diretoria é analisada com a remuneração média paga por diretor os resultados são diferentes: o aumento do número de diretores não eleva a remuneração média desse colegiado, pelo contrário, há evidência que quanto maior o número de diretores, menor será a remuneração média paga. E não foram encontradas evidências de que o número de conselheiros nas companhias afete a remuneração total ou média paga aos membros da diretoria.

O segmento de listagem em que a companhia negocia suas ações na BM\&FBOVESPA também mostrou ser relevante na remuneração paga aos diretores, em algumas regressões, como as da Tabela 10. Companhias listadas nos segmentos de maior governança corporativa da bolsa tendem a pagar mais de $50 \%$ a mais de remuneração variável para sua diretoria em comparação com aquelas companhias que não estão listadas nesses segmentos.

Considerando que há poucos estudos sobre o assunto no Brasil e que apenas a partir de 2009 houve uma exigência maior da CVM para a divulgação padronizada e mais bem detalhada sobre a remuneração de administradores das sociedades anônimas de capital aberto, há necessidade de estudos empíricos adicionais, utilizando outras variáveis mencionadas na literatura e possíveis de serem coletadas nas companhias listadas na BM\&FBOVESPA, tendo em vista que o assunto envolvendo remuneração dos administradores é de fundamental interesse para os acionistas das sociedades anônimas e aos investidores que pretendem alocar recursos nessas companhias.

Outra sugestão para trabalhos futuros sobre este tema é tentar buscar variáveis instrumentais para corrigir eventuais problemas de endogeneidade nas regressões realizadas. A questão de cada país ter um regulamento específico sobre a forma pela qual as companhias com ações listadas em bolsa de valores propõem e aprovam a remuneração dos seus respectivos administradores é um ponto também relevante, inclusive, para eventuais divergências em resultados encontrados, sendo uma sugestão para pesquisas futuras a 
elaboração de estudo comparado entre as principais jurisdicionais que possuam um mercado de capitais forte.

\section{Referências Bibliográficas}

ANTHONY, R N.; Govindarajan, v. Sistema de controle gerencial. Tradução: Adalberto Ferreira das Neves. São Paulo: Atlas, 2002.

ARAÚJO, Juliano Augusto; Parisi, Claudio; Da Silva, Ady Fernandes; Nakamura Wilson Toshiro. Remuneração de executivos e desempenho das companhias abertas brasileiras: uma visão empírica após a publicação da Instrução Normativa CVM 480, 2015. Disponível em: < http://www.etecnico.com.br/paginas/mef27005.htm >. Acesso em $15 / 1 / 2016$.

BALSAM, Steven. An Introdution to Executive Compensation. San Diego: academic press, 2002.

BARONTINI, Roberto, Bozzi, Stefano. Board Compensation and Ownership Structure: Empirical Evidence for Italian Listed Companies. Journal of Management and Governance, v. 15, p. 59-89, 2011.

BART, Bootsma. Pay-forperformance? An Empirical Investigation of the Relationshipbetween Executive Compensation and Firm Performance in the Netherlands. Dissertação de Mestrado. Erasmus School of Economics, Erasmus University Rotterdam, 2009.

BEBCHUK, Lucian A., Fried, Jesse M. Pay Without Performance. Journal of Applied Corporate Finance, v. 17, p. 8-23, 2005.

BEBCHUK, L.; FRíED, J. M. Executive compensation as an agency problem. Journal of Economic Perspective, Pittsburg, v. 17, n. 3, p. 71-92, 2003.

BRUNELLO, G. et al. Executive compensation and firm performance in Italy. International Journal of Industrial Organization, vol. 19(1), p. 133-161, 2001.

CAMARGO, Marcos Antônio, Helal, Diego Henrique. Análise Empírica da Relação entre a Remuneração de Executivos e o Desempenho Financeiro de Empresas Brasileiras. XXVII Encontro Nacional de Engenharia de Produção em Foz do Iguaçu, PR, Brasil, 2007.

CARPENTER, M. A.; SANDERS, W. G. Top management team compensation: the missing link between CEO pay and firm performance? Strategic Management Journal, Chicago, v. 23, n. 4, p. 367-375, 2002.

CHIEN, Alisson Chen Yi. A remuneração dos Executivos tem impacto no valor e 
desempenho das Empresas Brasileiras de Capital aberto? Dissertação de Mestrado. Escola de Pós-Graduação em Economia, Fundação Getúlio Vargas, 2012.

CISCEL, D. H.; CARROL, T. M. The determinants of executive salaries: an econometric survey. The Review of Economics and Statistics, Harvard, v. 62, n. 1, p. 7-13, 1980.

CONYON, M. J.; LEECH, D. Top pay, company performance and corporate governance. Oxford Bulletin of Economics and Statistics, Oxford, v. 56, n. 3, p. 332 - 351, 1994.

CONYON, M. J.; SADLER, G. V. Executive pay, tournaments and corporate performance in UK firms. International Journal of Management Review, London, v. 3, n. 2, p. 141-168, 2001.

DUFFHUES, Pieter, Kabir, Rezaul. Is the pay-performance relationship always positive? Evidence from the Netherlands. Journal of Multinational Financial Management, v. 18, p. 45-60, 2008.

ELSTON, J. A.; GOLDBERG, L. G. Executive compensation and agency cost in Germany. Journal of Banking \& Finance, Miami, v. 27, p. 1391-1410, 2003.

GRINSTEIN, Y; HRIBAR, P. CEO compensation and incentives: evidence from M\&A bonus. Journal of Financial Economics, New York, v. 73, n. 1, p. 119-143, 2004.

HSIAO, C. Analysis of panel data. Cambridge: Cambridge University Press, 2002.

JENSEN, M. C.; Meckling, W. H. Theory of the Firm: Managerial Behavior, Agency Costs and Ownership Structure. Journal of Financial Economics, v. 3, p 305-360, 1976.

JOHN E. Core, Robert W. Holthausen, David F. Larcker. Corporate governance, chief executive officer compensation, and firm performance. Journal of Financial Economics, v. 5, p 371-406, 1999.

KAPLAN, Steven N. Top Executive Reards and Firm Performance: A Comparison of Japan and the United States. Journal of Political Economy, v. 102, nº 3, pp. 510-546, 1994.

KRAUTEP, E. Contribuições do sistema de remuneração dos executivos para o desempenho financeiro: um estudo com empresas industriais brasileiras. 2009. 192f. Tese (Doutorado em Administração) - Universidade de São Paulo - FEA/USp, São Paulo, 2009.

MAIN, Brian G. M., Bruce, Alistair, Buck, Trevor. Total Board Remuneration and Company Performance. The Economic Journal, v. 106, p. 1627-1644, 1996.

McKNIGHT, P.An explanation of top executive pay: a UK study. British Journal of Industrial Relations, London, v. 3, n. 4, p. 557-566,1996.

MURPHY, Kevin J. Corporate Performance and Managerial Remuneration. Journal of Accounting and Economics, v.7, p. 11-42, 1985. 
MURPHY, Kevin J. Executive Compensation. Handbook of Labor Economics, v. 3, p. 2485- 2563, 1999.

PALIA, Hubbard, R. Glenn, Darius. Executive pay and performance Evidence from the U.S. banking industry. Journal of Financial Economics, v. 39, p. 105-130, 1995.

PINTO, Marcos Barbosa. Relação entre Dispersão Acionária e Remuneração dos Administradores de Companhias Abertas Brasileiras. Dissertação de Mestrado. Escola de Pós-Graduação em Economia, Fundação Getúlio Vargas, 2011.

RAO, P. S; LEE-SING, C. R. Governance structure, corporate decision-making and firm performance in North America. In: DANIELS, R. J.; MORCK, R. Corporate DecisionMaking; in Canada, Calgary: University of Calgary Press, 1995, p. 149-188.

SHAKERIN Bin Ismail, Natalie Vivienne Yabai, Low Joe Hahn. Relation between CEO Pay and Firm Performance: Evidences from Malaysia Listed Firms. Jounal of Economics and Finance, v. 3, p. 14-31, 2014.

SHIM, Daniel Eunsup. The Relationship Between Top Executive Compensation and Firm Performance in the Post Sabanes-Oxley Period. Advances in Management Accouting, v. 25, p. 207-228, 2015.

SILVA, Tarciso Gouveia da; ANDRADE, George Albin R. de. Utilização de modelos microeconômicos para previsão dos efeitos da teoria da agência nas organizações. Internext - Revista Eletrônica de Negócios Internacionais, São Paulo, v. 3, n. 1, p. 1-15, jan./jun. 2008.

STADLER, I.M.; CASTRILLO, J.D.P. An Introduction to the Economics of Information: Incentives and Contratcts. Oxford University Press, Second Edition, 2001.

TIROLE, J. The Theory of Industrial Organization. The MIT Press, Massachusetts, 1988.

VASCONCELOS, Adriana Fernandes; Monte, Paulo Aguiar. A remuneração de executivos e o desempenho financeiro das empresas brasileiras. Registro Contábil - Ufal - Maceió/AL, Vol. 4, $\mathrm{N}^{\mathrm{o}} 1$, p. 1-17, jan./abr. 2013.

WAN, K. M. Independent directors, executive pay, and firm performance. 2003. Disponível em: <https://www.researchgate.net/profile/Kam_Ming_Wan/publication/228225777_Independent _Directors_Executive_Pay_and_Firm_Performance/links/0046353224eea493f5000000.pdf/do wnload? version $=v t p>$. Acesso em: 28 mai. 2016.

WOOLDRIDGE, J. M. Introdução à Econometria: uma abordagem moderna. 4. ed. São Paulo: CENGAGE Learning, 2010. 
Quadro 1 - Matriz de correlação das variáveis não-binárias

\begin{tabular}{|c|c|c|c|c|c|c|c|c|c|c|c|c|c|c|c|c|c|c|c|c|c|c|c|}
\hline & $\mathbf{A F}$ & $\mathbf{A L}$ & $\mathbf{A R}$ & AV2 & BR & BS & $\mathbf{A X}$ & BD & BH & BJ & BT1 & BM & BN & BX & CL & CQ & CR & CY1 & $\mathrm{CO}$ & DA & \begin{tabular}{|l|} 
DTT \\
\end{tabular} & $\mathbf{A A}$ & $\mathbf{A S}$ \\
\hline $\mathbf{A F}$ & 1,00 & & & & & & & & & & & & & & & & & & & & & & \\
\hline $\mathbf{A L}$ & 0,83 & 1,00 & & & & & & & & & & & & & & & & & & & & & \\
\hline $\mathbf{A R}$ & 0,83 & 0,94 & 1,00 & & & & & & & & & & & & & & & & & & & & \\
\hline AV2 & 0,82 & 0,92 & 0,97 & 1,00 & & & & & & & & & & & & & & & & & & & \\
\hline BR & 0,38 & 0,74 & 0,86 & 0,76 & 1,00 & & & & & & & & & & & & & & & & & & \\
\hline BS & 0,67 & 0,40 & 0,47 & 0,54 & 0,31 & 1,00 & & & & & & & & & & & & & & & & & \\
\hline BD & 0,51 & 0,61 & 0,57 & 0,53 & 0,08 & 0,03 & 0,81 & 1,00 & & & & & & & & & & & & & & & \\
\hline BH & 0,34 & 0,03 & 0,48 & 0,46 & 0,36 & 0,00 & 0,28 & 0,50 & 1,00 & & & & & & & & & & & & & & \\
\hline BJ & 0,66 & 0,74 & 0,76 & 0,73 & 0,18 & 0,10 & 0,85 & 0,92 & 0,66 & 1,00 & & & & & & & & & & & & & \\
\hline BT1 & 0,29 & 0,35 & 0,28 & 0,22 & 0,27 & 0,16 & 0,36 & 0,51 & 0,64 & 0,52 & 1,00 & & & & & & & & & & & & \\
\hline $\mathbf{B M}$ & 0,26 & 0,18 & 0,39 & 0,28 & 0,34 & 0,17 & 0,43 & 0,62 & 0,72 & 0,81 & 0,89 & 1,00 & & & & & & & & & & & \\
\hline BN & 0,20 & 0,15 & 0,26 & 0,18 & 0,18 & 0,17 & 0,36 & 0,50 & 0,57 & 0,60 & 0,70 & 0,62 & 1,00 & & & & & & & & & & \\
\hline CL & 0,40 & 0,62 & 0,46 & 0,44 & $-0,01$ & $-0,01$ & 0,51 & 0,58 & 0,47 & 0,63 & 0,26 & 0,01 & 0,08 & $-0,01$ & 1,00 & & & & & & & & \\
\hline CQ & 0,03 & $-0,01$ & 0,02 & 0,02 & 0,06 & 0,05 & 0,03 & 0,00 & $-0,02$ & 0,02 & 0,05 & 0,05 & 0,08 & $-0,08$ & 0,01 & 1,00 & & & & & & & \\
\hline CR & 0,02 & $-0,03$ & 0,01 & 0,01 & 0,01 & 0,02 & 0,01 & 0,00 & $-0,01$ & 0,01 & 0,00 & 0,07 & 0,02 & $-0,05$ & 0,01 & 0,89 & 1,00 & & & & & & \\
\hline CY1 & 0,02 & 0,03 & 0,01 & 0,01 & 0,02 & 0,02 & 0,01 & 0,00 & $-0,24$ & $-0,04$ & $-0,15$ & $-0,22$ & $-0,42$ & $-0,05$ & 0,01 & 0,60 & 0,68 & 1,00 & & & & & \\
\hline $\mathrm{CO}$ & \begin{tabular}{|l|}
0,00 \\
\end{tabular} & 0,03 & 0,00 & 0,01 & 0,01 & $-0,01$ & 0,01 & 0,02 & 0,01 & 0,01 & 0,01 & 0,01 & 0,03 & 0,03 & 0,01 & 0,02 & 0,01 & 0,01 & 1,00 & & & & \\
\hline DA & 0,02 & 0,03 & 0,03 & 0,03 & 0,09 & 0,01 & 0,01 & $-0,01$ & 0,00 & 0,02 & 0,00 & 0,02 & $-0,02$ & 0,01 & $-0,01$ & $-0,01$ & $-0,07$ & 0,01 & 0,06 & 1,00 & & & \\
\hline DTT & $-0,02$ & $-0,06$ & 0,01 & 0,01 & 0,01 & 0,00 & $-0,03$ & $-0,04$ & $-0,02$ & $-0,02$ & 0,01 & 0,04 & $-0,01$ & $-0,03$ & $-0,04$ & $-0,02$ & 0,10 & $-0,04$ & 0,04 & 0,19 & 1,00 & & \\
\hline $\mathbf{A A}$ & 0,17 & $-0,01$ & 0,11 & $-0,01$ & 0,05 & 0,03 & 0,15 & 0,12 & 0,21 & 0,15 & 0,29 & 0,22 & 0,23 & $-0,09$ & 0,09 & 0,06 & 0,04 & 0,03 & $-0,01$ & 0,02 & 0,00 & 1,00 & \\
\hline AS & 0,57 & 0,71 & 0,66 & 0,66 & 0,02 & 0,02 & 0,80 & 0,72 & 0,29 & 0,84 & 0,17 & 0,11 & 0,04 & $-0,04$ & 0,63 & 0,04 & 0,02 & 0,02 & 0,01 & 0,04 & 0,01 & 0,14 & 1,00 \\
\hline
\end{tabular}

Período analisado: de 2010 a 2014. (i) variáveis relativas aos membros do conselho de administração - AF: remuneração fixa. AL: remuneração variável. AR: remuneração total (fixa + variável + outras). AV2: remuneração média dos membros do CA. BR: valor da maior remuneração entre os membros do CA. BS: valor da menor remuneração entre os membros do CA. (ii) variáveis relativas aos membros da diretoria - AX: remuneração fixa. BD: remuneração variável. BH: remuneração em ações. BJ: remuneração total (fixa + variável + ações + outras). BT1: remuneração média. BM: valor da maior remuneração entre os membros da Diretoria. BN: valor da menor remuneração entre os membros da Diretoria. BX: percentual do capital votante do acionista com mais ações ordinárias, ON. CL: ativo total. CQ: ROA: \% (Lucro líquido / Ativo Total) - ano corrente. CR: ROA_1: \% (Lucro líquido / Ativo Total) - 1 ano defasado. CY1: ROA_2: \% (Lucro líquido / Ativo Total) - 2 anos defasados. CO: LPA: (lucro líquido / total de ações). DA: percentual de retorno das ações em 12 meses - ano corrente. DTT: percentual de retorno das ações em 12 meses - 1 ano defasado. AA: número de membros no CA. AS: número de membros na diretoria. 